\title{
New insights into the geological structure of the Netherlands; results of a detailed mapping project
}

\author{
H. Kombrink ${ }^{1,2}$, J.C. Doornenbal ${ }^{1,}{ }^{*}$, E.J.T. Duin ${ }^{1}$, M. den Dulk ${ }^{1}$, S.F. van Gessel ${ }^{1}$, \\ J.H. ten Veen ${ }^{1} \&$ N. Witmans ${ }^{1}$ \\ 1 TN0 - Geological Survey of the Netherlands, P.0. Box 80015, 3508 TA Utrecht, the Netherlands. \\ 2 Present address: Total E\&P UK, Crawpeel Road, AB12 3FG, Aberdeen, United Kingdom. \\ * Corresponding author. Email: hans.doornenbal@tno.nl.
}

Manuscript received: July 2011, accepted: November 2011

\begin{abstract}
A five years geological mapping project, in which the Netherlands Continental Shelf has been re-examined using all publicly available data, resulted in an important update of the existing dataset. The stratigraphy of over 400 wells has been re-interpreted. New depth and thickness grids, based mainly on the interpretation of 3D seismic data have been produced for the most important stratigraphic intervals from Permian Upper Rotliegend to Neogene. New reservoir grids describe the top, base and thickness of 30 (potential) reservoir units in the area. In addition, the uncertainty related to interpretation and further processing of the data has been assessed. This resulted in maps displaying the standard deviation for the depth of the main stratigraphic intervals. Based on these results and the data already available for the onshore area, an updated structural element map was made for the Netherlands.
\end{abstract}

Keywords: Geological mapping, the Netherlands, 3D subsurface model, uncertainties, structural elements

\section{Introduction}

The Geological Survey of the Netherlands (TNO) carried out a few major mapping projects over the last decades in order to better understand the deep subsurface of the on- and offshore areas. In 2004 an overview of onshore mapping was published to commemorate the end of a project which started in 1985 (TNO-NITG, 2004). Subsequently, the NCP-1 project (Nederlands Continentaal Plat, Netherlands Continental Shelf) was performed as a screening study to make sure a set of depth maps was available for the offshore area (2004-2006; Duin et al., 2006) and to obtain a regional framework for the mapping project to come (NCP-2). This paper summarises the results of the NCP-2 follow-up project, which entailed a detailed interpretation of well and 3D seismic data (Fig. 1). In addition, the mapping and modelling (integration into the time and depth grids) of over 3500 faults has significantly increased the quality of the grids. Age dating of a selection of key-wells led to a better understanding of the structural and depositional history.
Depth and thickness maps have been made for 11 intervals (Fig. 2): the Upper Rotliegend Group (Late Permian), the Zechstein Group (Late Permian), the Lower and Upper Germanic Trias groups, the Altena Group (Early and Middle Jurassic), the Posidonia Shale Formation (only depth map), the SchielandScruff groups (Late Jurassic-Early Cretaceous), the Rijnland Group (Early Cretaceous), the Chalk Group (Late CretaceousEarly Paleogene), the Lower and Middle North Sea groups (Paleogene) and the Upper North Sea Group (Neogene). These maps are a compilation of onshore grids (1985-2004 mapping project and updates) and the NCP-2 maps created for the offshore. The grids of the depth are presented here (Figs 7a-j); both depth and thickness maps can be downloaded (www.nlog.nl). With the integration of stratigraphic well tops and depth grids of the main horizons, depth and thickness maps of the main reservoir intervals in the offshore area have been constructed (30 reservoirs in total, examples are given in Figs $11 \mathrm{a}$ and $11 \mathrm{~b}$ ). In addition, new tectonostratigraphic diagrams were made, which give an overview of the stratigraphic development of the 

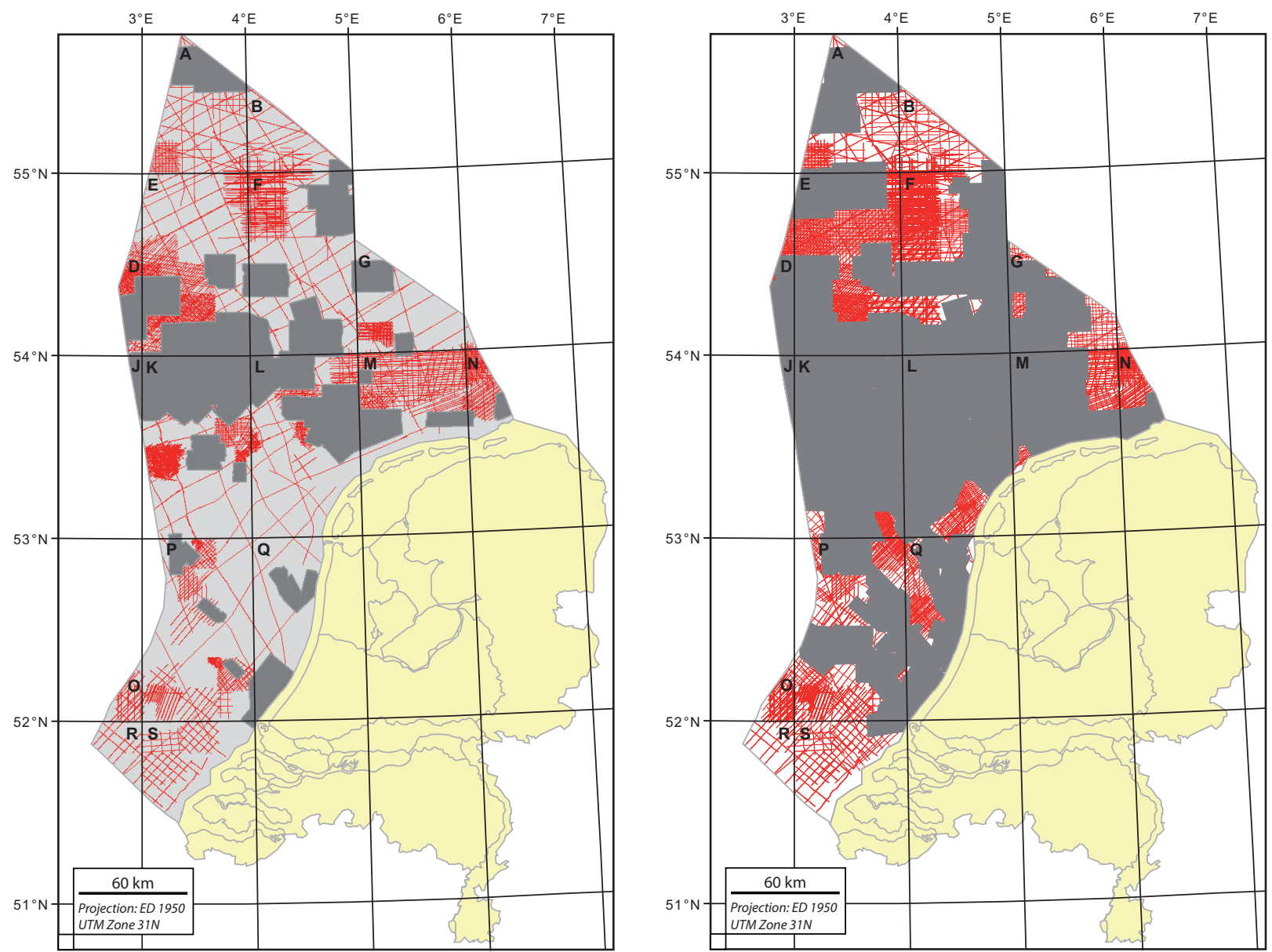

Fig. 1. Maps showing the seismic data used for the NCP-1 (left) and NCP-2 projects.

main basins and platforms in the Netherlands offshore area (example in Fig. 8). Finally, a new structural elements map was compiled for the Late Jurassic/Early Cretaceous period based on a rationalisation of the most recent structural elements map (Duin et al., 2006; Figs 12 and 13).

\section{Geological setting}

The Netherlands was located on a few small micro-continents in between major and rigid cratonic areas (Pharaoh, 1999; Ziegler, 1990). This explains the continued and renewed tectonic activity (mainly in the form of net subsidence) in the area. For an extensive description of the geological development of the Netherlands and surrounding areas, the reader is referred to Wong et al. (2007a), McCann (2008a), McCann (2008b), Doornenbal \& Stevenson (2010) and Ziegler (1990). Here, a concise summary is presented.

During most of the Devonian, the Netherlands was part of the northern shelf of the relatively narrow Rheno-Hercynian basin that stretched from Cornwall in the west to the eastern part of Germany (Bless et al., 1980; Oncken et al., 2000). The Caledonian mountain belt in the north provided sediments that are now probably present underneath most of the Netherlands but have rarely been encountered in boreholes. In the northern offshore area (Elbow Spit High), seismic data suggest the presence of a
Middle Devonian Kyle limestone equivalent. The sparsely drilled Upper Devonian succession suggests a fluvio-lacustrine depositional environment (Old Red Group; Geluk et al., 2007). In the southern part of the Netherlands, marine conditions prevailed during the Middle and Late Devonian (Banjaard Group).

In Carboniferous times, the Rheno-Hercynian Ocean that separated Gondwana-derived terranes from the Laurussian continent was gradually closed, leading to the Variscan Orogeny (Oncken et al., 1999). The Netherlands were located in the northern foreland of this mountain range. During the Early Carboniferous, the northern offshore area was a site of deltaic sedimentation derived from the North (Farne Group), while further south clastic sedimentation was much more limited. Here, carbonate platforms developed with intervening sedimentstarved basins (Carboniferous Limestone Group; Kombrink et al., 2010; Van Hulten \& Poty, 2008). In Late Carboniferous (Namurian) times, siliciclastic sedimentation rates increased, leading to the burial of the carbonate platforms and the infilling of the deep basins. Large amounts of sediment from the rising orogen to the South were shed into this basin. The Westphalian shows a continuing regressive mega-trend, evidenced by deposition of fluvio-deltaic sediments and a high number of coals (Limburg Group). By the end of the Carboniferous sedimentation came to an end with the completion of the Variscan orogenesis. 


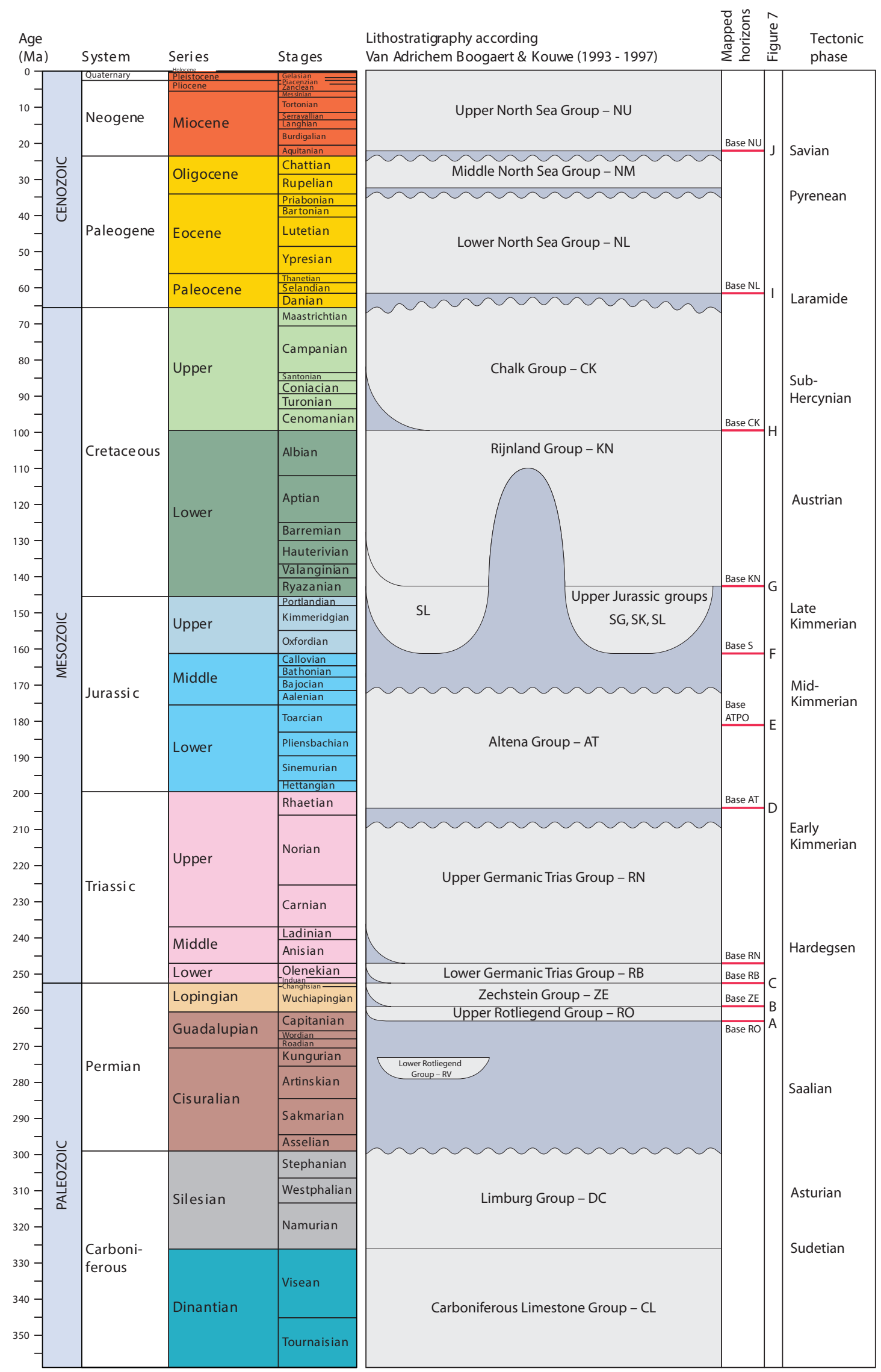

Fig. 2. Simplified stratigraphic diagram of the Netherlands showing the age and names of the main intervals of which the base has been mapped in the available seismic data. Please note that the base Upper Rotliegend grid has not been obtained by seismic interpretation. First, a thickness map for the Rotliegend was made using all the available well data. The depth of the base Rotliegend has subsequently been calculated by adding the thickness map to the base Zechstein grid. 
A major hiatus, caused by large scale wrenching and upwarping of the foreland due to the collapse of the Variscan orogen, separates Carboniferous from Permian rocks (Van Wees et al., 2000). Apart from local volcanic deposits (Emmen Volcanics Formation), the oldest Permian sediments in the Netherlands reflect deposition in an arid environment (Upper Rotliegend Group; Brouwer, 1972). Deposition took place in an east-west trending sag basin, the Southern Permian Basin. Fluvial and aeolian sandstones with a southern provenance prograded northwards into a playa basin characterised by fine-grained deposition and intercalated halites (Silverpit Fm.; Geluk, 2007a). A thick sequence of cyclic marine evaporites of the Zechstein Group covers the Rotliegend topography, except for the southern offshore area where the Zechstein is developed in a basin fringe facies (Geluk, 2005).

In Triassic times, Pangea gradually started to break up, leading to initial extensional faulting in the Netherlands (Dutch Central Graben; De Jager, 2007). However, the Southern Permian Basin continued to subside regularly, leading to an uninterrupted transition from the Zechstein to the Triassic (Geluk, 2005). The Early Triassic was characterised by deposition of playa shales, followed by an alternation of fluvial and aeolian sandstones and lacustrine shales during the Olenekian (Lower Germanic Trias Group). Separated by the Base Solling Unconformity (Hardegsen phase) the Upper Germanic Trias Group rests upon the Lower Germanic Trias Group. Gradually, marine influence became more prominent as a connection with the Tethys 0cean in the south was established (Geluk, 2007b). Initially, an alternation of evaporates (Röt Evaporites) and fluviolacustrine sediments were deposited, which were gradually replaced by fully marine marls and limestones of the Muschelkalk Formation. Uplift of the Fennoscandian High in response to rifting of the Viking Graben (Paul et al., 2009) and probably a more humid climate during the Ladinian led to an increased siliciclastic (fine-grained) sediment supply from the north. These sediments, including the intercalated lagoonal and evaporitic succession are known as the Keuper Formation.

The Triassic-Jurassic boundary marks the transition from shallow marine deltaic sedimentation to fully marine deposition of argillaceous sediments (Altena Group). Marine sedimentation continued into the Bajocian, probably also outside the Jurassic graben areas (Lott et al., 2010). In Aalenian times, an extensive thermo-magmatic uplift (Mid-Kimmerian phase) in the Central North Sea caused significant erosion of Jurassic and Triassic strata in the north of the Netherlands (Underhill \& Partington, 1993). From the 0xfordian to the Ryazanian, sedimentation was restricted to the main rift-basins such as the Dutch Central Graben and the Broad Fourteens Basin. The development of these rift basins is attributed to the Late Kimmerian rifting phase. Late Jurassic to earliest Cretaceous fluvio-lacustrine sediments filled these rift basins (Schieland and Scruff groups).

During the Early Cretaceous, sea-level rise and broad thermal subsidence caused deposition to progressively overstep the margins of these rift basins (Herngreen \& Wong, 2007). At the base of this transgressional sequence (Rijnland Group), sandstones of the Vlieland Formation are deposited (Den Hartog Jager, 1996; Dunay \& Dronkers, 1983). The Vlieland Shale Formation, consisting of marine fine-grained sediments, covers this complex of barrier systems and shallow marine strongly bioturbated sandstones in most places. As a consequence of continuing sea-level rise, sediment input gradually decreased, which led to the deposition of marine carbonates. Initially, an alternation of marls and claystones of the Holland Formation was deposited, followed by pure limestones of the Chalk Group (Van der Molen, 2004). In Late Cretaceous times, the northward movement of Africa caused increased compressional stresses in the Netherlands, leading to the first of a series of inversion phases (De Jager, 2003).

In the Early Paleogene new inversion phases caused increase in sediment supply, which resulted in a change from a carbonate dominated environment to siliciclastic deposition (North Sea Super Group; Wong et al., 2007b). At least three inversion phases temporarily interrupted sedimentation in the Cenozoic: the Laramide, Pyrenean and Savian phases (De Lugt, 2007). Distal marine sedimentation, alternated with progradation of shallow marine sands characterised the Paleogene. In Late Miocene and Pliocene times, a huge delta system which is commonly referred to as the Eridanos delta (Overeem et al., 2001), prograded westwards from Scandinavia and Denmark and filled up the remaining accommodation space.

\section{Methods}

The geological model presented in this paper comprises eleven major stratigraphic units (Fig. 2). The applied modelling workflow is common practice in oil and gas exploration and includes the interpretation of horizons and faults from $3 \mathrm{D}$ and $2 \mathrm{D}$ seismic data in time domain (two-way traveltime) and the subsequent conversion to the depth domain using a velocity model built from well log and checkshot data. The interpreted well markers help identify the horizons in the seismic data and provide an anchorpoint for a tie to the correct depth after conversion.

\section{Well log interpretation}

For the offshore area more than 400 publicly available wells have been interpreted (Fig. 3). The available logs for the selected wells include gamma-ray, sonic and occasionally also neutrondensity logs which are all combined in consistent composite log files. The criteria for selection of the wells were total depth, stratigraphic significance, spatial distribution, presence of digital well logs and cores.

The composite logs of all wells were lithostratigraphically (re-)interpreted up to member level. The construction of several cross-sections within each sub area allowed a detailed lithostratigraphic interpretation. The interpretation of the composite 


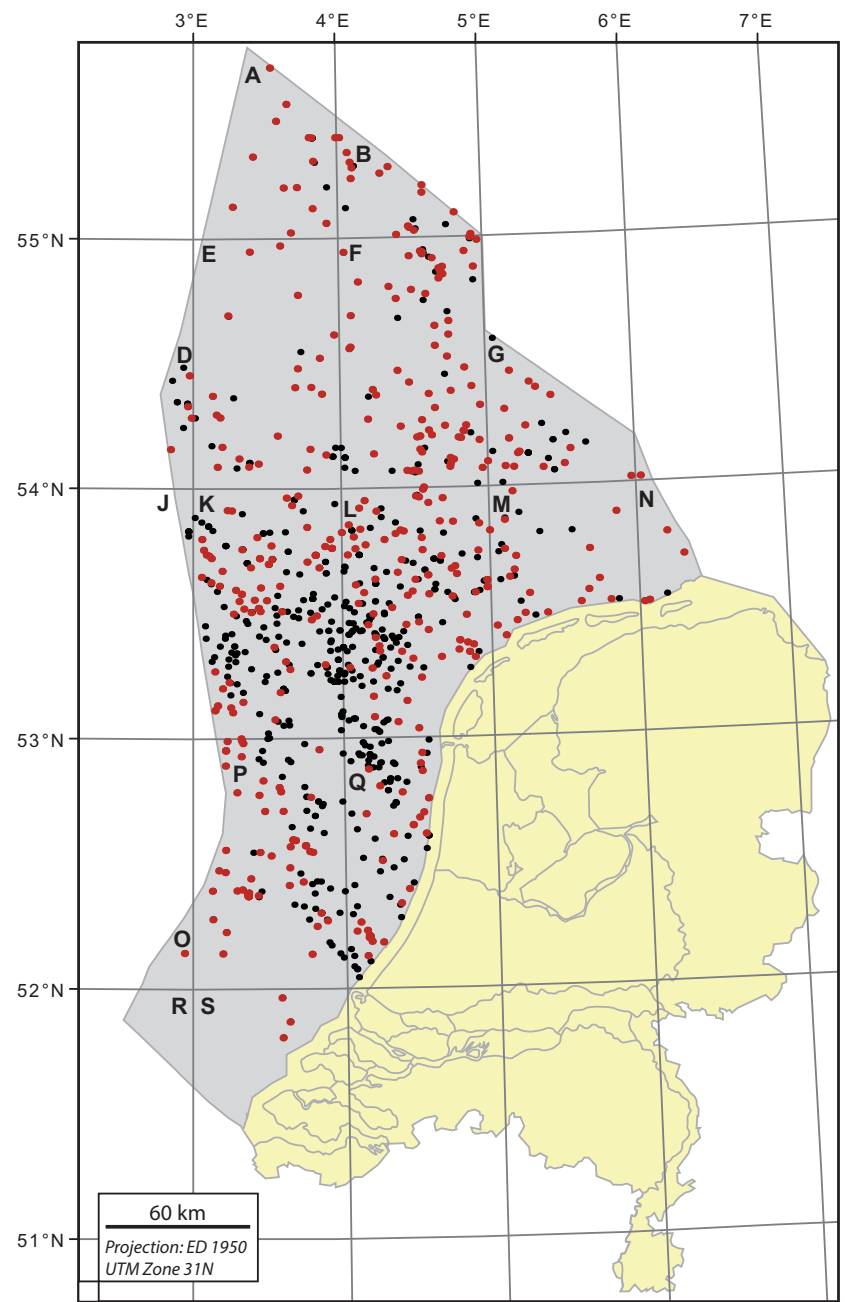

Fig. 3. All wells in the offshore area (red and black) of which the red ones have been (re-)interpreted.

well logs resulted in a more detailed lithostratigraphic subdivision of the area. The stratigraphic information was included in the interpretation of the seismic data and formed the basis of several biostratigraphic (Munsterman et al. this issue) and sedimentological studies (Stegers, 2006). In addition, the tops and bases of the main reservoir units that were identified in the wells have been used to create thickness and distribution maps of these reservoir units. The interpretations are available through the NLOG website (www.nlog.nl).

\section{Seismic interpretation}

In large parts of the Netherlands offshore area 3D seismic data have been acquired mainly by the oil industry and service companies. In the NCP-1 project the interpretations of a number of these 3D surveys were used in the mapping of the subsurface (Duin et al, 2006). For the NCP-2 project all available non-confidential 3D seismic surveys were used to interpret the boundaries of eleven major stratigraphic units, from the Late Permian Upper Rotliegend Group up to the Neogene Upper North Sea Group (Fig. 2). In general, every $10^{\text {th }}$ to $20^{\text {th }}$ inline and crossline has been interpreted in the 3D surveys, corresponding to a $250 \mathrm{~m}$ resolution. Areas not covered by 3D seismic surveys are filled in with interpretations from 2D seismic surveys.

The interpreted boundaries are presented in Fig. 2. In the NCP-1 project the bases of the Upper Germanic Trias Group and the Posidonia Shale Formation were not interpreted. The units are defined in the stratigraphic nomenclature of the Netherlands (Van Adrichem Boogaert \& Kouwe, 1993). In general, the base of the Zechstein Group is the oldest stratigraphic horizon interpreted using seismic data. In the deep parts of the Broad Fourteens Basin and the Dutch Central Graben the base of the Zechstein could not be interpreted. In these areas an isopach grid, based on well data and surrounding interpreted seismic data, is added to the depth of the base of the Triassic. The base of the Upper Rotliegend Group is constructed by adding an isopach grid, based on well data, to the depth of the base Zechstein horizon. Intra-Carboniferous strata are interpreted on several platform areas where data of sufficient quality are available, like in the $\mathrm{D}$ and $\mathrm{E}$ quadrants and the southern offshore area.

The interpreted horizons are merged into one compiled model in the two-way time domain. Minor inconsistencies between the interpretations of different surveys due to differences in acquisition and processing were analysed and minimised by applying individual vertical shifts and local smoothing. Individual horizons have been gridded into an areal grid with cells of $250 \mathrm{~m} \times 250 \mathrm{~m}$ using a convergent gridding algorithm.

\section{Time-depth conversion}

The horizons and faults are converted to a depth domain using a layer cake velocity model of type:

$$
\mathrm{V}(\mathrm{x}, \mathrm{y}, \mathrm{z})=\mathrm{V}_{0}(\mathrm{x}, \mathrm{y})+\mathrm{K} \cdot \mathrm{z}
$$

\section{Where:}

$\mathrm{V}(\mathrm{x}, \mathrm{y}, \mathrm{z})=$ velocity of the layer at depth $\mathrm{z}$

$\mathrm{V}_{0}(\mathrm{x}, \mathrm{y})=$ velocity at ordnance level

$\mathrm{K}$ = factor determining the linear increase of velocity with depth

Except for the Zechstein Group, this model assumes that the acoustic velocity of a layer increases linearly with depth under the influence of burial and compaction. The Zechstein layer predominantly consists of high velocity carbonate and halite for which no clear relationship between seismic velocity and depth exists.

The parameters $\mathrm{V}_{0}$ and $\mathrm{K}$ are determined in the VELMOD project from checkshots and sonic logs of over 1500 wells (Van Dalfsen et al., 2006). The model parameter $\mathrm{K}$ is determined from the linear least squares relationship between the interval velocity $\left(\mathrm{V}_{\text {int }}\right)$ and mid-depth $\left(\mathrm{z}_{\mathrm{mid}}\right)$ of the layer (Table 1). It is assumed that this parameter is independent of location, except for the 
Table 1. $V_{\text {int }}-z_{\text {mid }}$ linear regression parameters for the compacting layers. Territory (see column 'Area') means that those values represent the entire offshore area, while Region indicates part of the offshore area, whereby $A=$ Dutch Central Graben, $B=$ Broad Fourteens Basin, Central Netherlands Basin and Lower Saxony Basin and $C=$ Vlieland Basin, Terschelling Basin and Step Graben.

\begin{tabular}{llllll}
\hline Main layer & Area & $\begin{array}{l}\# \\
\text { Holes }\end{array}$ & $\begin{array}{l}\text { K } \\
\left(\mathbf{s}^{-1}\right)\end{array}$ & $\begin{array}{l}\mathbf{V}_{\mathbf{0}} \\
\left(\mathbf{m s}^{-1}\right)\end{array}$ & $\begin{array}{l}\text { Cor. } \\
\text { Coef. (r) }\end{array}$ \\
\hline Cenozoic & Territory & 598 & 0.321 & 1757 & 0.849 \\
\hline Upper Cretaceous & Territory & 680 & 0.864 & 2359 & 0.844 \\
\hline Lower Cretaceous & Territory & 756 & 0.508 & 2120 & 0.781 \\
\hline Upper Jurassic & Region A & 52 & 0.805 & 1090 & 0.794 \\
\hline Upper Jurassic & Region B & 127 & 0.635 & 2334 & 0.705 \\
\hline Upper Jurassic & Region C & 41 & 0.854 & 1209 & 0.819 \\
\hline Lower Jurassic & Region A & 17 & 0.601 & 1559 & 0.880 \\
\hline Lower and Middle Jurassic & Region B & 165 & 0.484 & 2221 & 0.783 \\
\hline Middle and Upper Triassic & Territory & 353 & 0.374 & 3185 & 0.578 \\
\hline Lower Triassic & Territory & 466 & 0.417 & 3087 & 0.582 \\
\hline
\end{tabular}

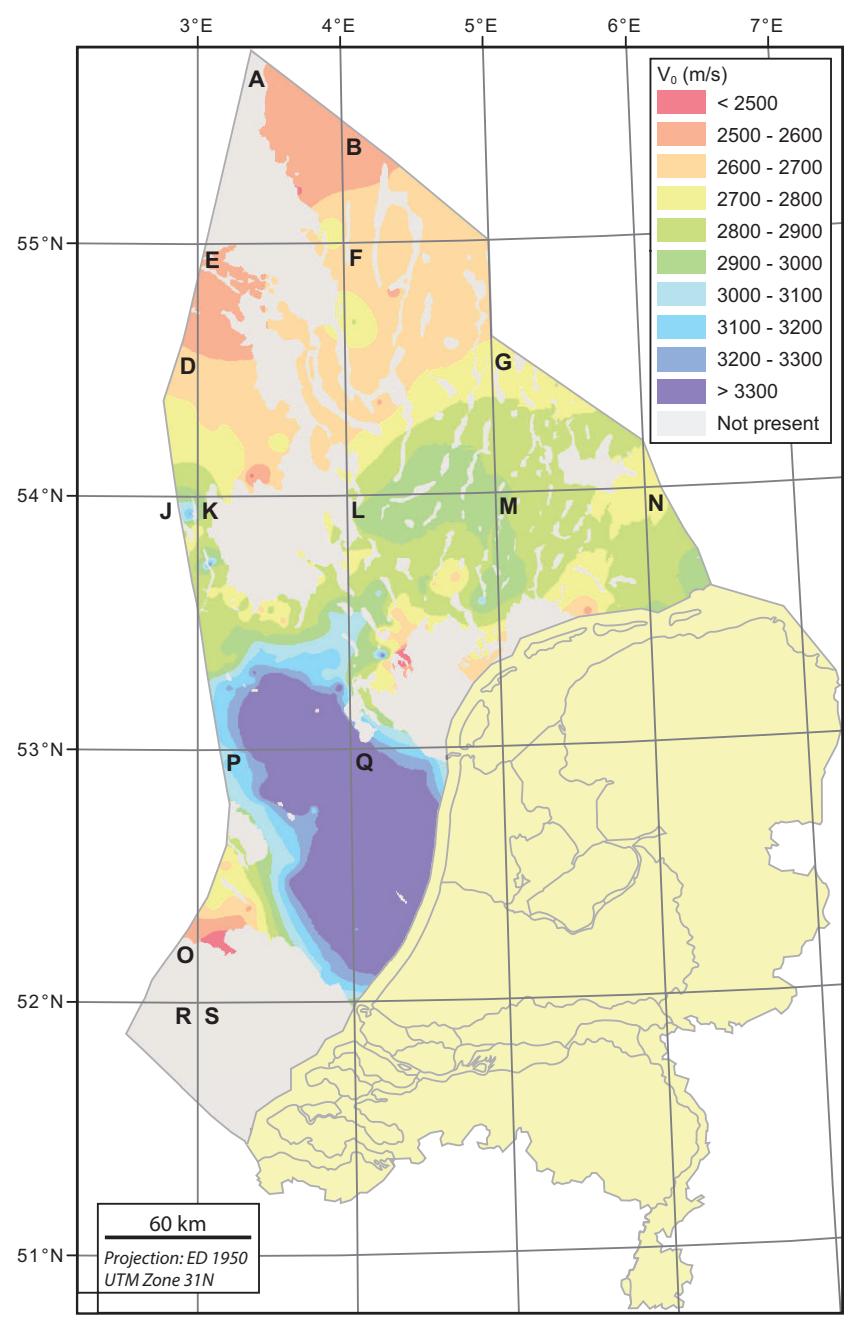

Fig. 4. V V-distribution of the Lower Germanic Trias Group.
Jurassic layers (Schieland Group and Altena Group) where $\mathrm{K}$ varies across the different basins (fig. 6 in Van Dalfsen et al., 2006).

The location dependent parameter $\mathrm{V}_{0}(\mathrm{x}, \mathrm{y})$ is determined at borehole locations by:

$$
\mathrm{V}_{0}(\mathrm{x}, \mathrm{y})=\mathrm{K} \cdot[\mathrm{zb}-\mathrm{zt} \cdot \exp (\mathrm{K} \cdot \Delta \mathrm{T})] \cdot[\exp (\mathrm{K} \cdot \Delta \mathrm{T})-1]^{-1}
$$

This relationship implies that the model travel time between top (at $\mathrm{zt}$ ) and base (at $\mathrm{zb}$ ) of the layer equals the travel time $\Delta \mathrm{T}$ according to the sonic data. Ordinary block kriging was applied to the $\mathrm{V}_{0}$-values at borehole locations to obtain grids $(1 \mathrm{~km} \times 1 \mathrm{~km})$ of both $\mathrm{V}_{0}$ and its kriging standard deviation (Figs 4 and 5). Major variations in the distribution of $V_{0}(x, y)$-values often coincide with regions of Late Cretaceous and Cenozoic structural inversion (relatively high velocities) and regions where overpressured conditions are present within layers (relatively low velocities). This observation further supports the decision to subdivide the model according to the major Mesozoic structural elements.

As mentioned above, the $\mathrm{V}_{0}-\mathrm{K}$ model does not apply to the Zechstein Group. For this group a provisional grid of interval

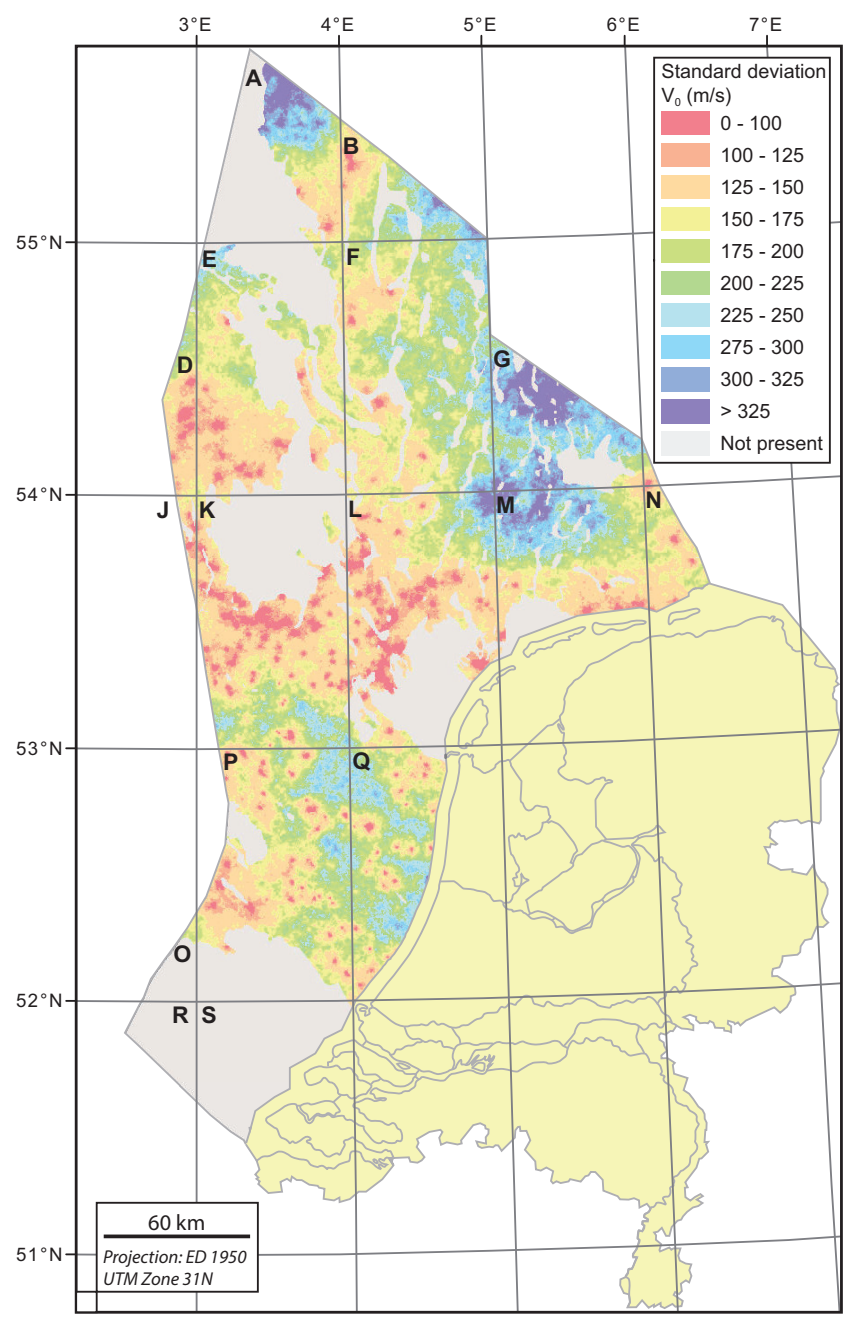

Fig. 5. Standard deviation of $V_{0}$ of the Lower Germanic Trias Group. 


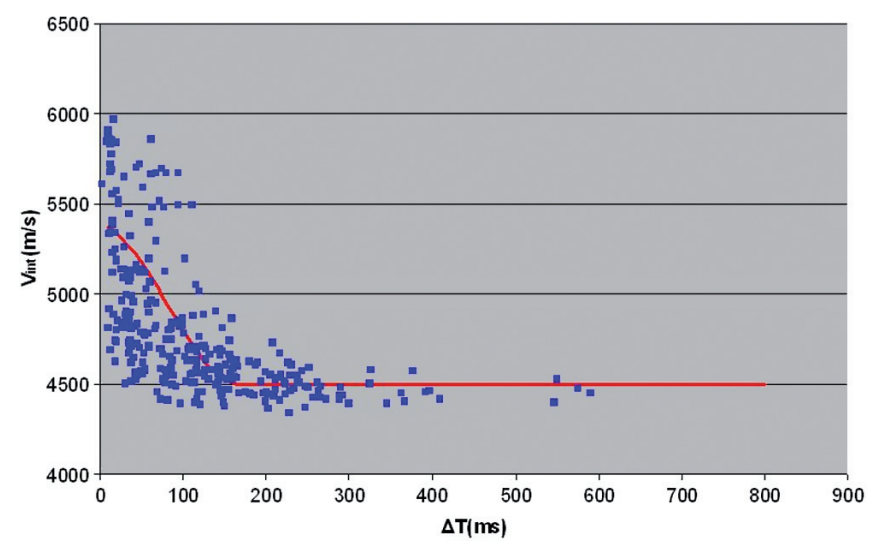

Fig. 6. Relation between $V_{\text {int }}$ and $\Delta T$ (Zechstein Group) at borehole locations. The high velocity values at $\Delta T<170 \mathrm{~ms}$ reflect the relative abundance of high velocity carbonate layers.

velocities is built based on the travel times from seismic interpretation and a correlation between the $\mathrm{V}_{\text {int }}$ and $\Delta \mathrm{T}$-data in wells:

$$
\begin{array}{ll}
\mathrm{V}_{\text {intprov }}=4500 \mathrm{~m} / \mathrm{s} & \text { if } \Delta \mathrm{TZE} \geqslant 170 \mathrm{~ms} \\
\mathrm{~V}_{\text {intprov }}=4950-450 \cdot \cos (\Delta \mathrm{TZE}+10) & \text { if } \Delta \mathrm{TZE}<170 \mathrm{~ms}
\end{array}
$$

The final $V_{\text {int }}$-grid was obtained by kriging the difference ( $\left.\mathrm{V}_{\text {intprov }}-\mathrm{V}_{\text {intborehole }}\right)$ at borehole locations, and by subtracting the kriged differences from the $\mathrm{V}_{\text {intprov}}$-values. In this step the minimum $V_{\text {int }}$-value in the final velocity grid was constrained to $4400 \mathrm{~m} / \mathrm{s}$.

After time-depth conversion, the misties of each horizon grid with the well marker depths are kriged over the model area. Abnormally high mistie values, caused by local features such as salt domes and faults, are filtered out and corrected locally. The resulting mistie grids are combined with the timedepth converted grids to obtain a stratigraphic model that acknowledges the well data (Figs $7 a-j$ ).

The base of the Zechstein Group often suffers from a severe over- or underestimation of depth below salt domes due to a problematic identification of this interface in the seismic surveys. A correction is applied here by clipping these areas and subsequently determining the depth values through interpolation.

\section{Fault modelling}

For the offshore area around 3800 faults were interpreted, depth converted and stored in a fault data base. Faults were interpreted if a significant offset of the horizons can be seen over a certain distance and if they are important in terms of structuration. The offshore of the Netherlands has been subdivided in 7 smaller subareas and fault models were built for each of these subareas. Resulting grids and fault lines are published on NLOG.nl. In total a selection of about 2500 faults were incorporated in the models.

\section{Uncertainty analyses}

The methodology described above concerns a deterministic mapping workflow. It produces best estimates of depth based on the interpreter's insight of where data is available. In areas without data the depths are estimated using standard interpolation algorithms. This method produces geologically sound maps but does not provide information concerning the reliability of the modelled depths and thicknesses.

In order to present a measure of the reliability for the depth of the modelled layers, a stochastic uncertainty workflow has been developed. This workflow is essentially similar to the deterministic workflow described in the previous section (i.e. building time maps for each horizon from seismic interpretations that are subsequently converted to the depth domain using an acoustic velocity model), but also takes into account the potential error bandwidth for each data source. A stochastic algorithm (Sequential Gaussian Simulation, SGS) is applied to interpolation in order to generate multiple random realisations for each horizon (time and depth domain). Each realisation is conditioned to the available data but varies within the set error bandwidth away from the points.

The workflow takes into account three error sources which are combined in the final uncertainty maps:

1. Data error - This error takes into account any error related to the picking of a horizon within a seismic dataset including processing errors, vertical shifting errors and resolution errors. In general the data error is relatively small (standard deviation 5-20 ms) and increases with depth due to decreasing quality of the seismic data (e.g. lower resolution and more problematic processing). A larger error is assumed for picks traced from 2D seismic than from 3D seismic. The data error is added as a noise factor to the original horizon picks using a short correlation distance $(<1 \mathrm{~km})$.

2. Structural error - This error is associated with the interpolation of the time maps. Areas characterised by low structural complexity and gentle features (e.g. platforms and highs) will produce small errors with interpolation, while in structurally complex areas (e.g. large fault offsets, salt doming) a significant error is introduced when large gaps exist between data points. The potential error that may be introduced with interpolation is determined by calculating moving standard deviation maps for the depth of each layer using a search window of $5 \times 5 \mathrm{~km}$. These maps represent the regional variation of potential interpolation error magnitude which defines the bandwidth within which the SGS interpolation algorithm simulates the horizon depths. At the location of data points, the depth values will range within the data error bandwidth. Moving away from data points, the error gradually increases up to the maximum interpolation error set by the regionally varying structural error. A variogram model defines the correlation between the depth values and the way the error bandwidth increases away from the data points. 


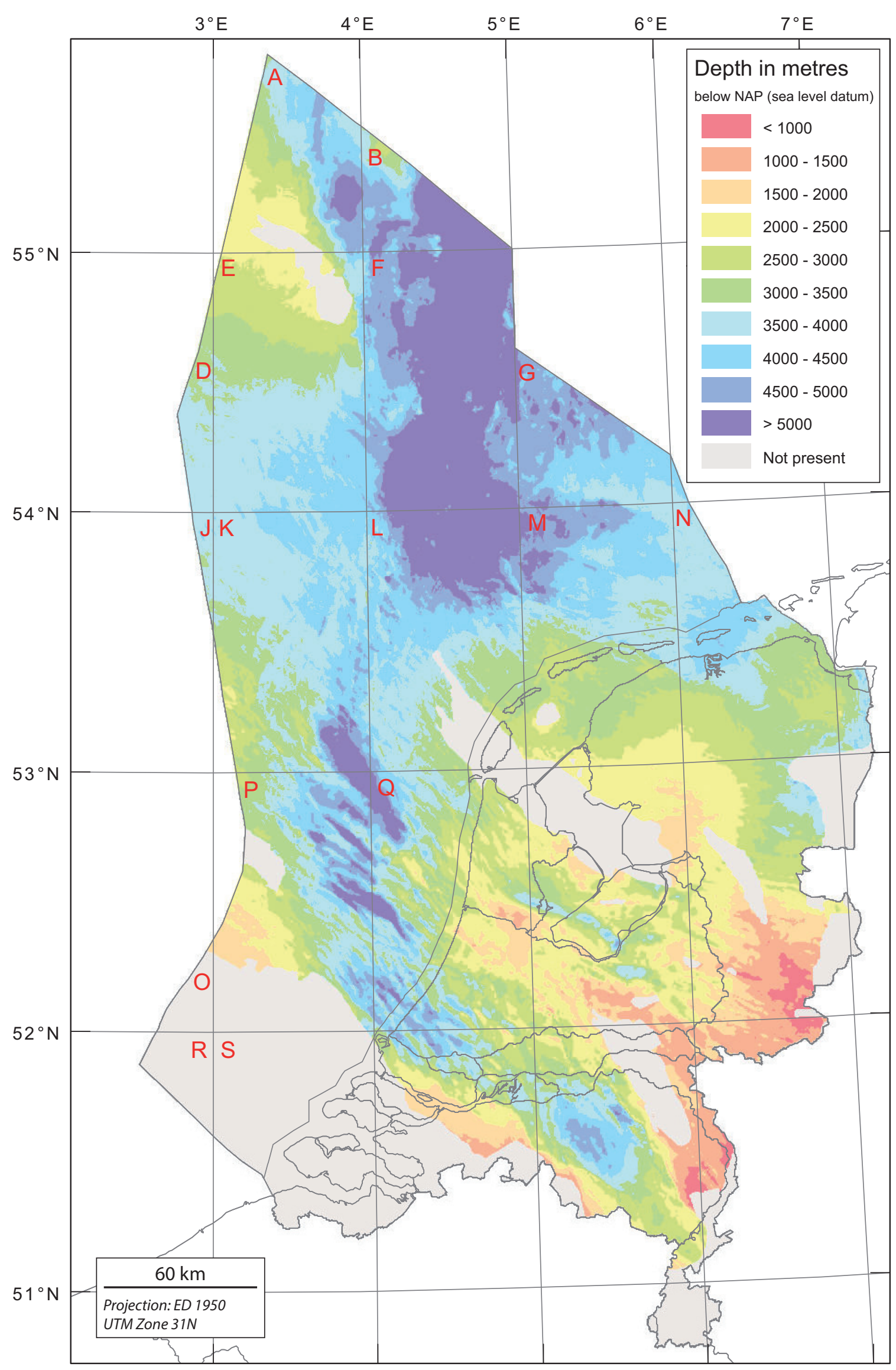

Fig. 7a. Depth of the base of the Upper Rotliegend Group (Late Permian). The offshore area is the result of the NCP-2 project described here, the onshore is an update of the mapping project presented in TNO-NITG (2004). 


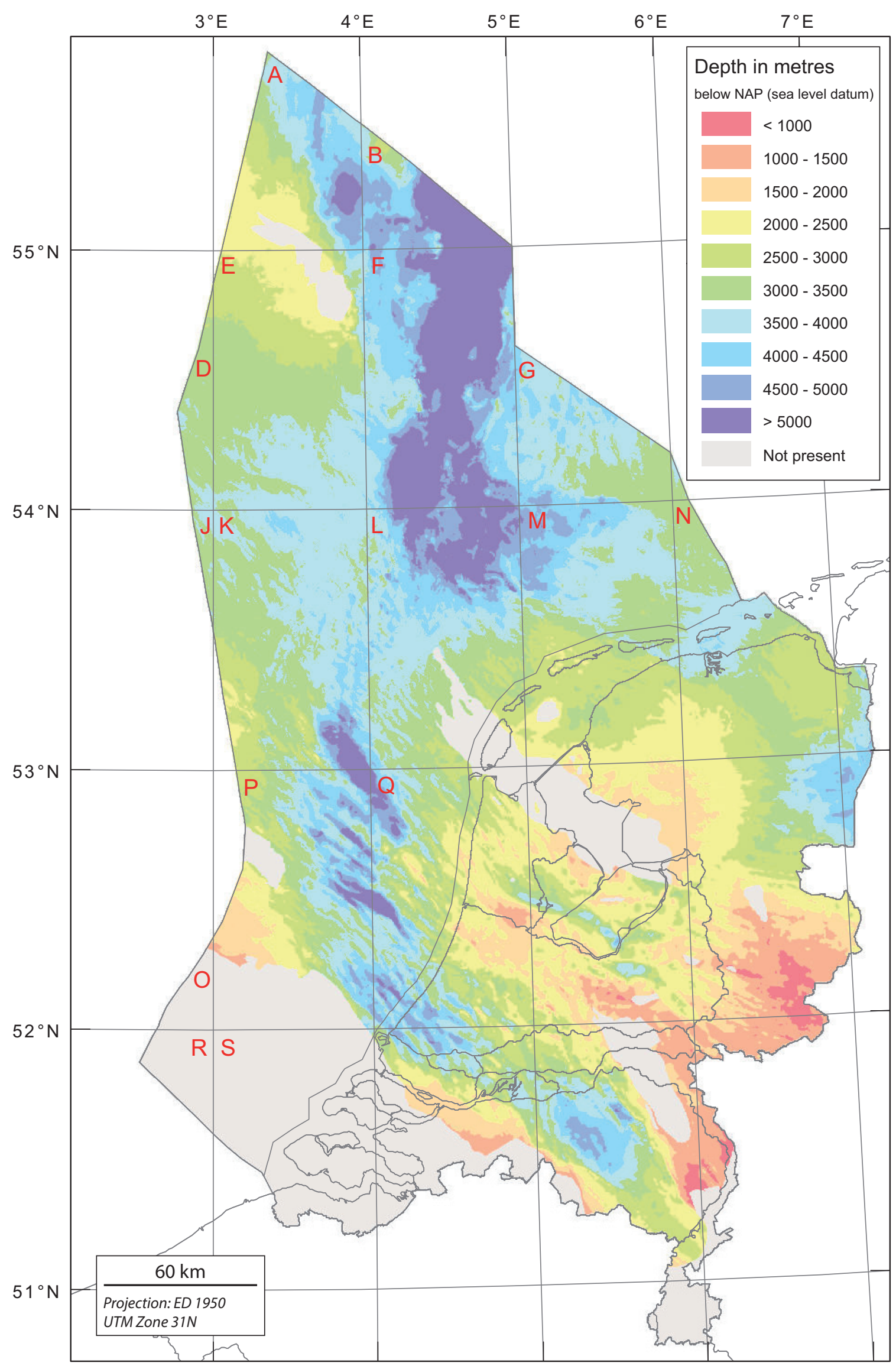

Fig. 7b. Depth of the base of the Zechstein Group (Late Permian). The offshore area is the result of the NCP-2 project described here, the onshore is an update of the mapping project presented in TNO-NITG (2004). 


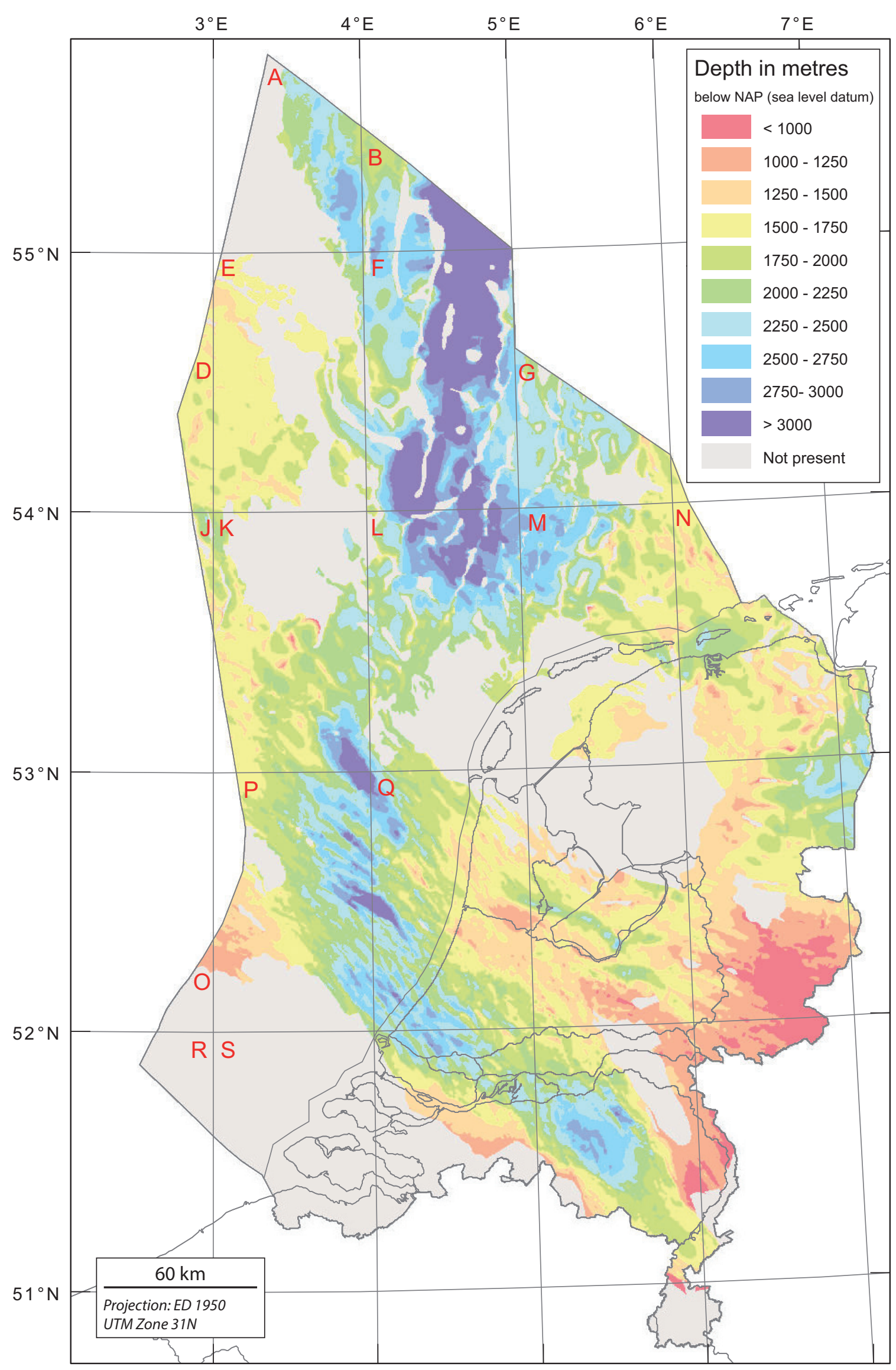

Fig. 7c. Depth of the base of the Lower Germanic Trias Group. The offshore area is the result of the NCP-2 project described here, the onshore is an update of the mapping project presented in TNO-NITG (2004). 


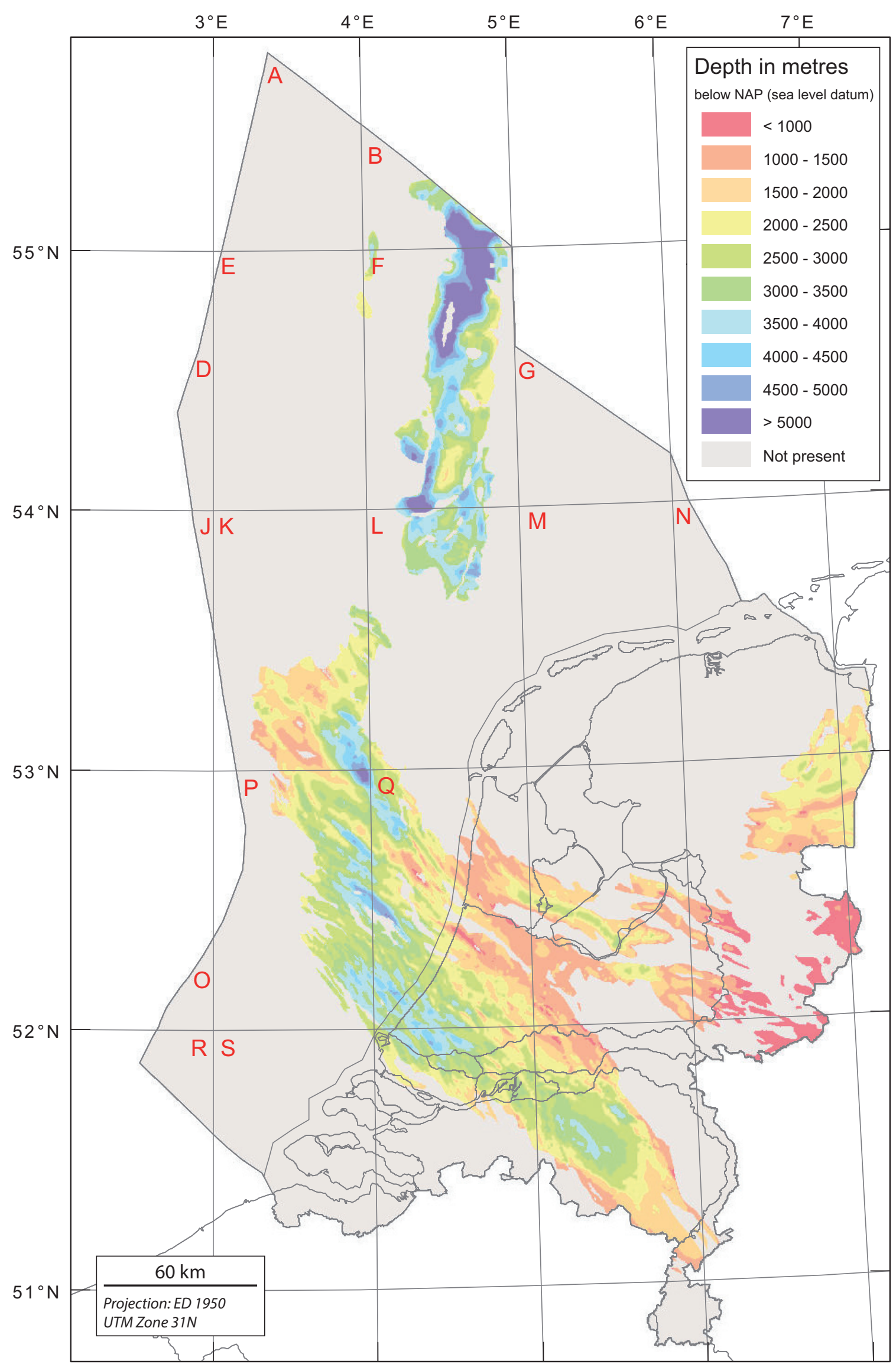

Fig. 7d. Depth of the base of the Altena Group (Early and Middle Jurassic). The offshore area is the result of the NCP-2 project described here, the onshore is an update of the mapping project presented in TNO-NITG (2004). 


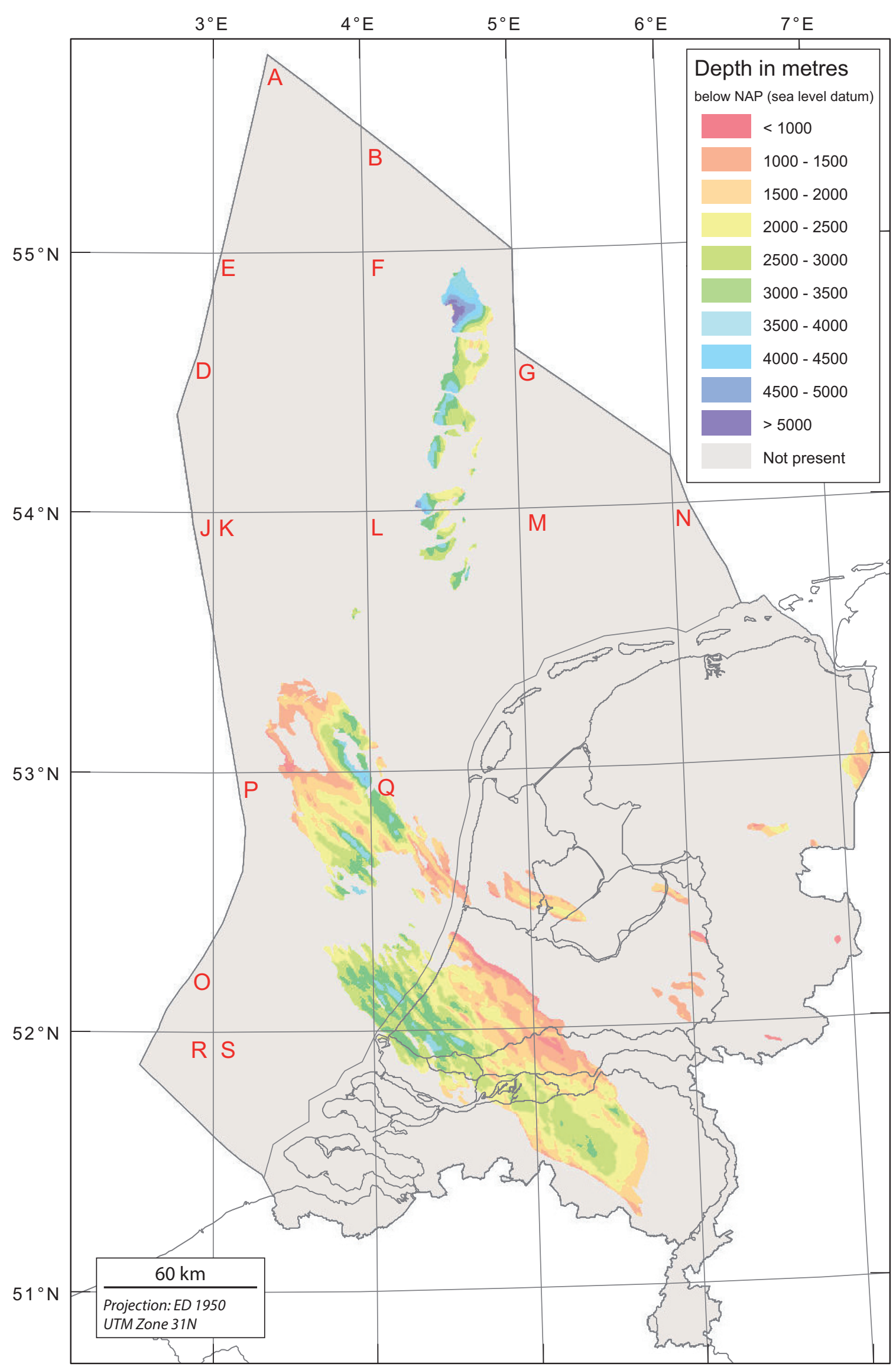

Fig. 7e. Depth of the base of the Posidonia Shale Formation (Middle Jurassic). The offshore area is the result of the NCP-2 project described here, the onshore is an update of the mapping project presented in TNO-NITG (2004). 


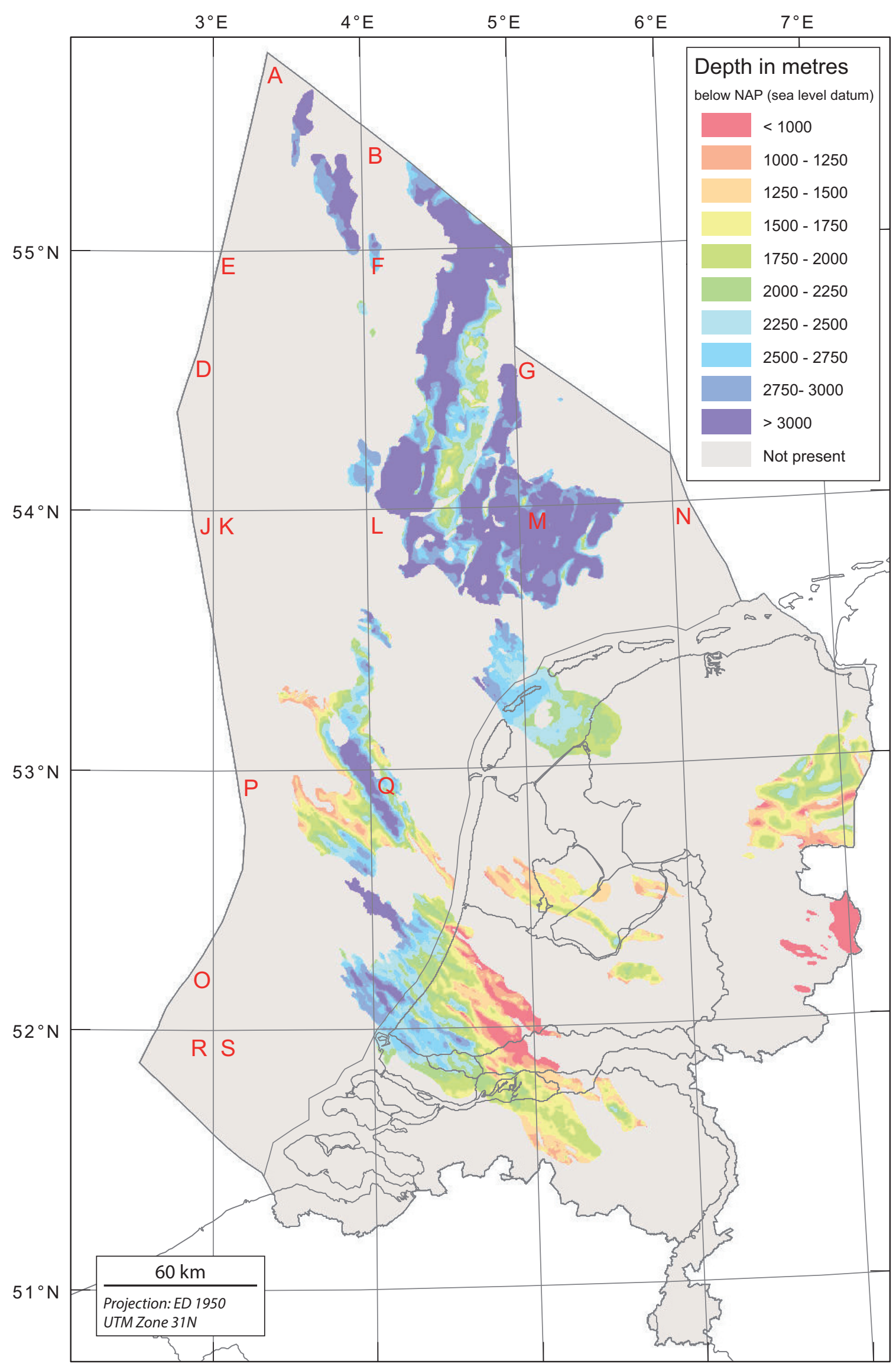

Fig. 7f. Depth of the base of the Schieland, Scruff and Niedersachsen groups (Late Jurassic). The offshore area is the result of the NCP-2 project described here, the onshore is an update of the mapping project presented in TNO-NITG (2004). 


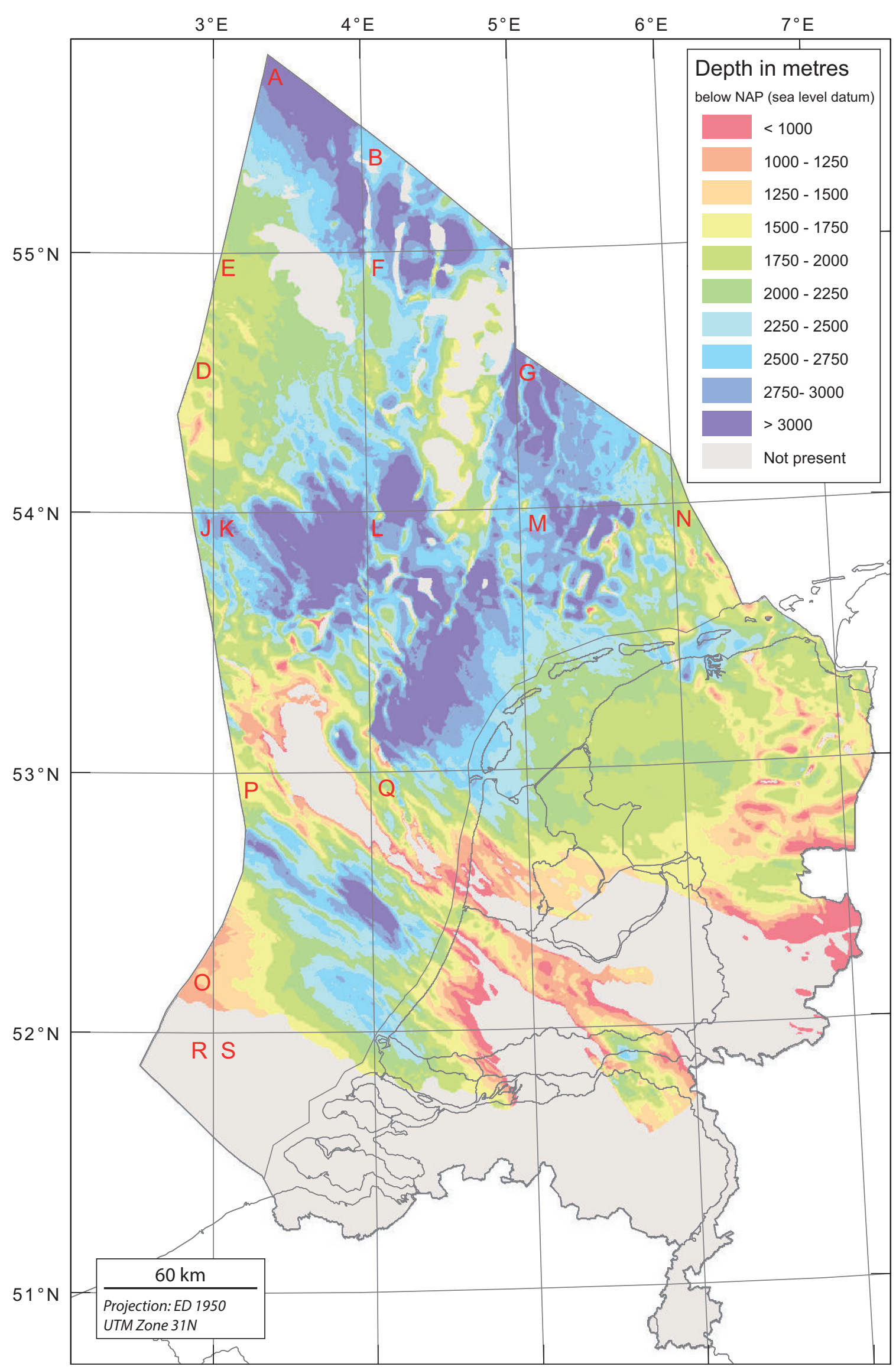

Fig. 7g. Depth of the base of the Rijnland Group (Early Cretaceous). The offshore area is the result of the NCP-2 project described here, the onshore is an update of the mapping project presented in TNO-NITG (2004). 


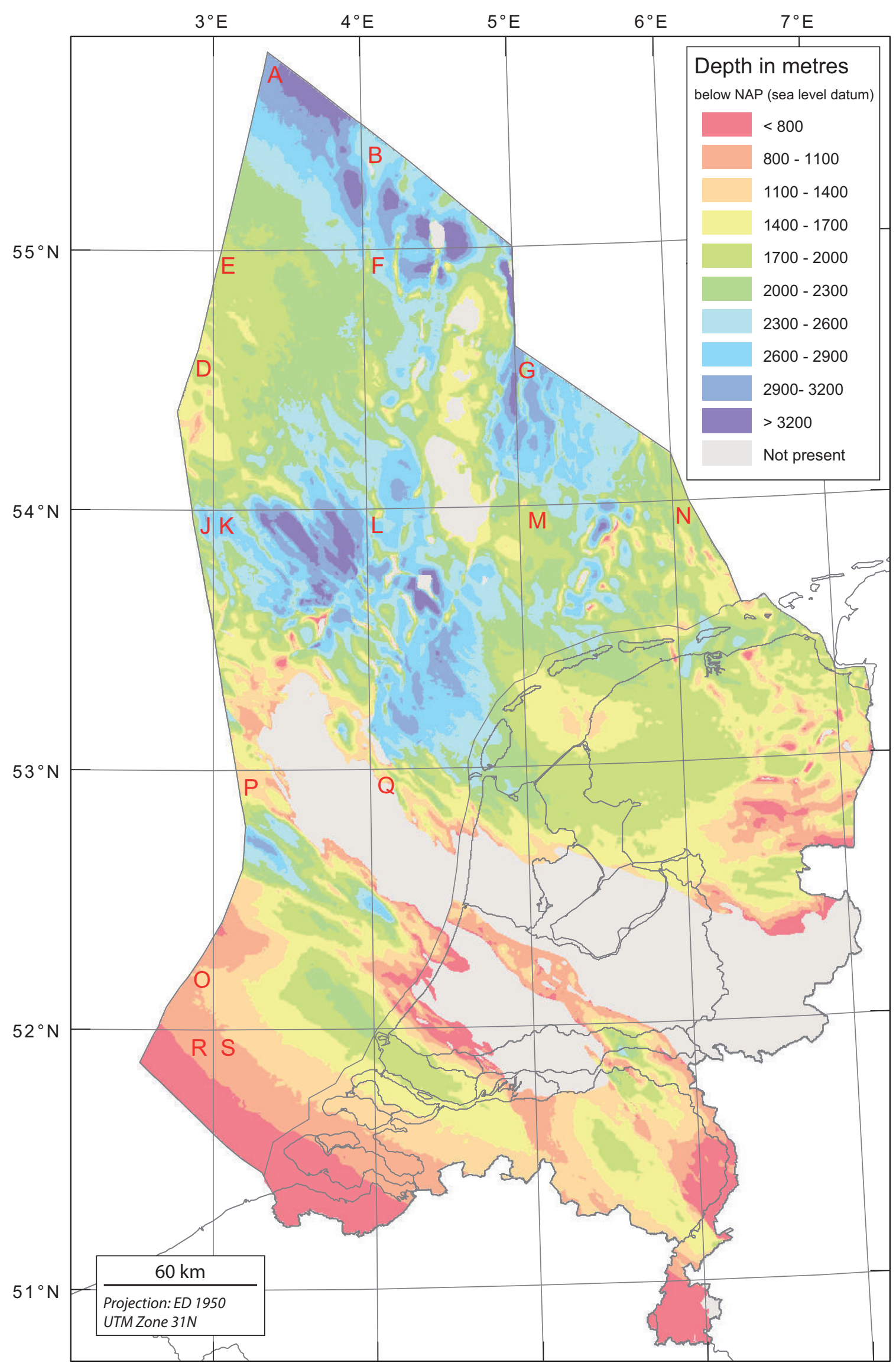

Fig. 7h. Depth of the base of the Chalk Group (Late Cretaceous). The offshore area is the result of the NCP-2 project described here, the onshore is an update of the mapping project presented in TNO-NITG (2004). 


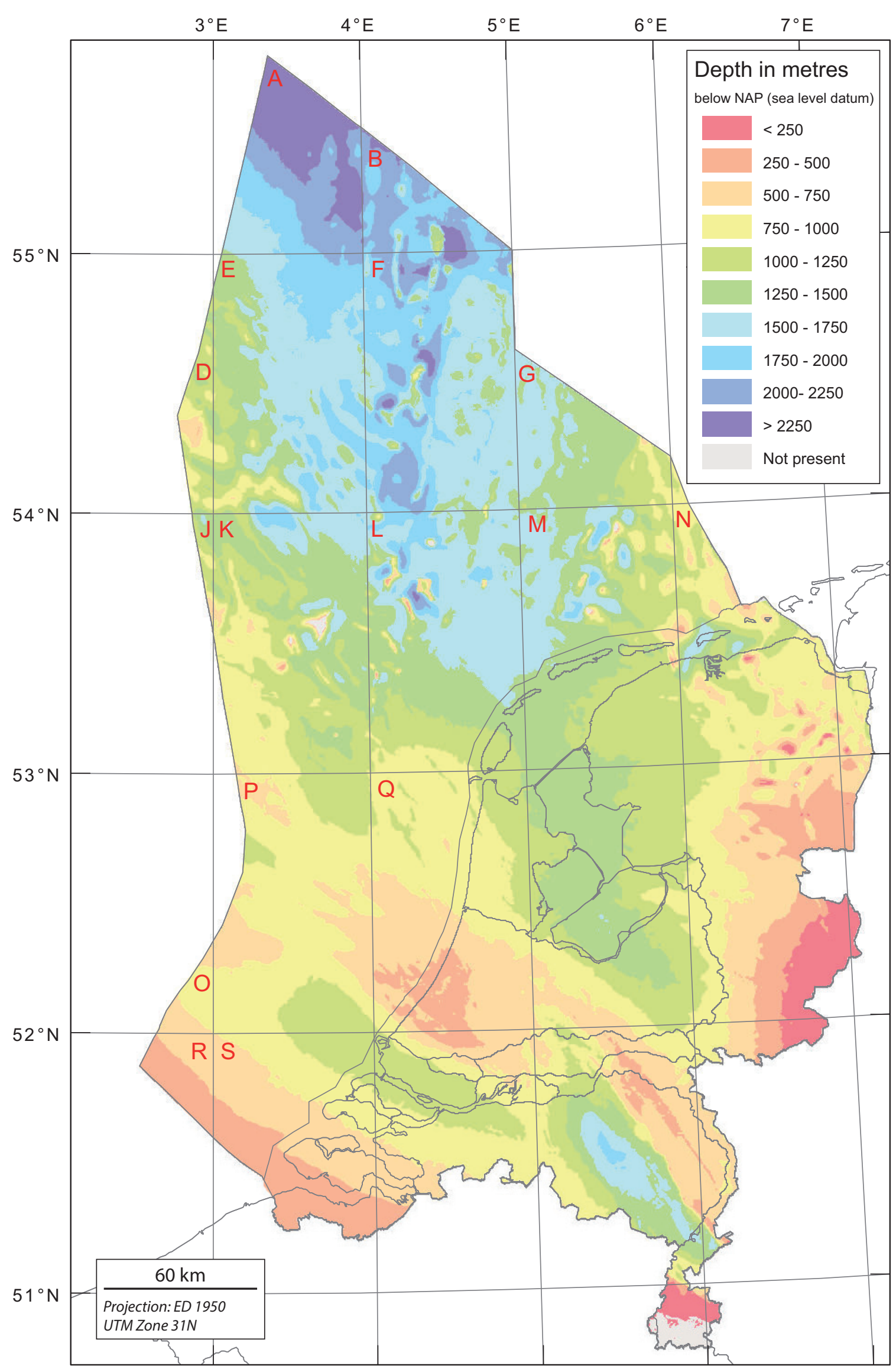

Fig. 7i. Depth of the base of the North Sea Supergroup (Paleogene). The offshore area is the result of the NCP-2 project described here, the onshore is an update of the mapping project presented in TNO-NITG (2004). 


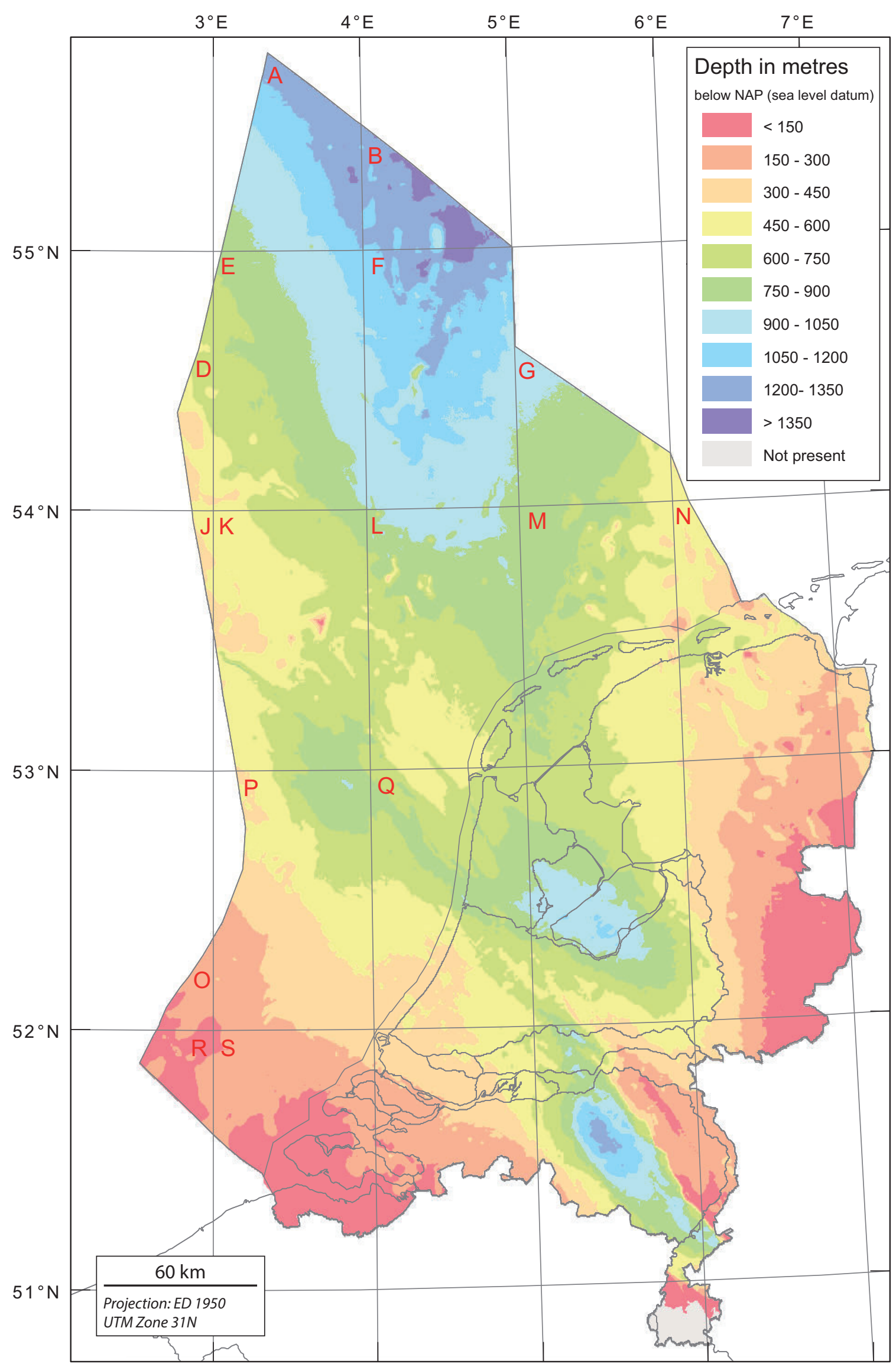

Fig. 7j. Depth of the base of the Upper North Sea Group (Neogene). The offshore area is the result of the NCP-2 project described here, the onshore is an update of the mapping project presented in TNO-NITG (2004). 


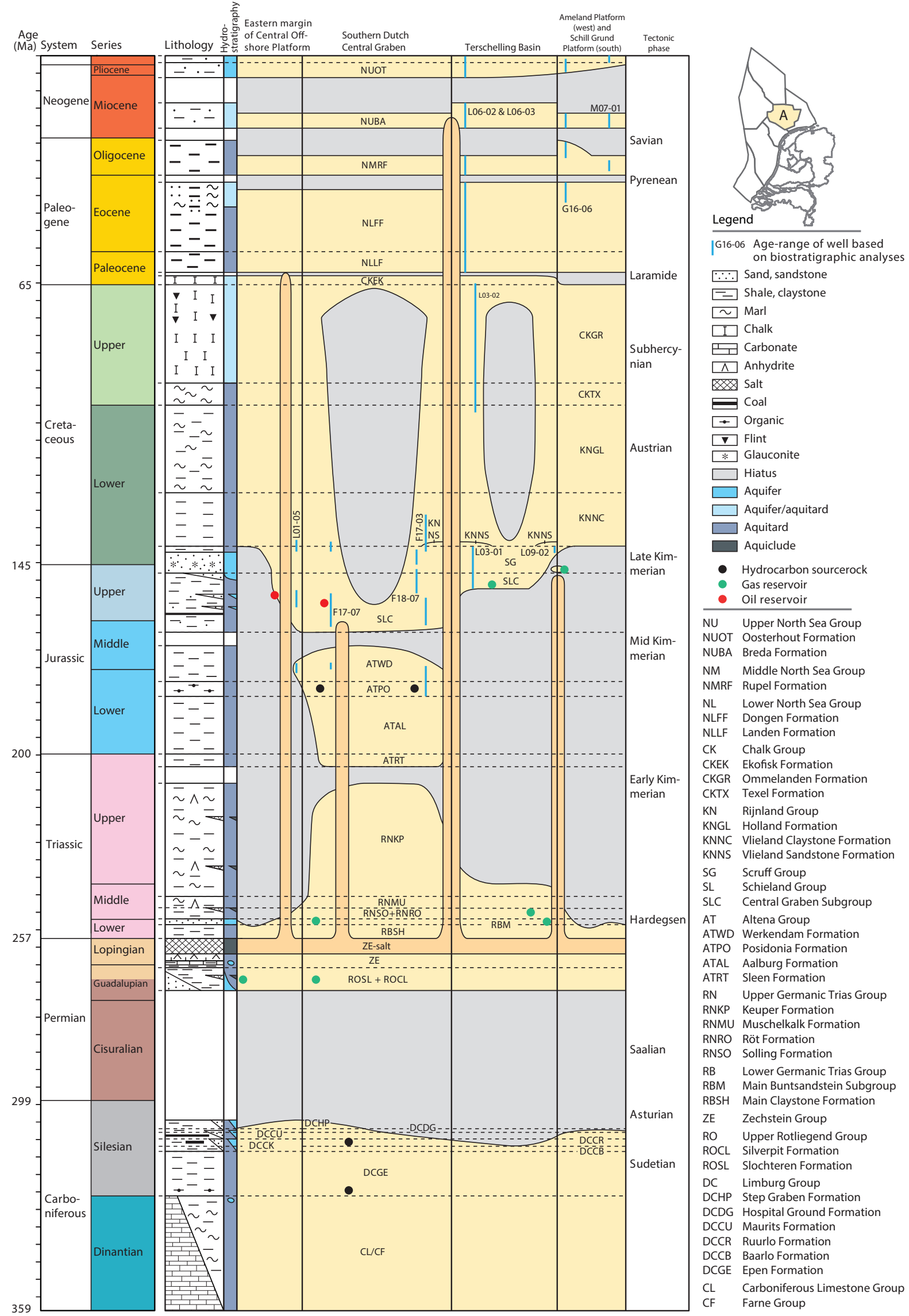

Fig. 8. Tectonostratigraphic chart of the Terschelling Basin and surrounding platform areas. Timescale and ages mostly according to Gradstein et al. (2004), except 1) the Triassic (according to Kozur \& Bachmann, 2008); 2) the Upper Jurassic (according to Munsterman et al., this issue); and 3) the Quaternary (according to the International Commission on Stratigraphy (ICS), 2008). The Western European nomenclature is used for the Carboniferous series and stages. 
3. Velocity model error - The values of the velocity model include a large uncertainty as they are based on a relatively sparse borehole dataset and the determination of acoustic velocities in itself often incorporates a lot of uncertainties. Furthermore, the errors generated with the time-depth conversion of shallow layers will propagate to the depth conversion of deeper layers. For each map of $V_{0}$, a set of SGS realisations has been calculated using the same interpolation and variogram settings as used in the VELMOD model (Van Dalfsen et al., 2006). Finally, all errors are combined to a joint depth error following these steps:

- A random depth-dependent data error is added to all seismic horizon picks.

- A random realisation of a set of time domain maps for each horizon is obtained from SGS interpolation of the seismic horizon picks (plus error) in combination with the regional structural error maps.

- A random realisation of $V_{0}$ maps for each horizon is obtained from SGS interpolation of all available well velocity determinations and variogram and interpolation parameters from VELMOD.

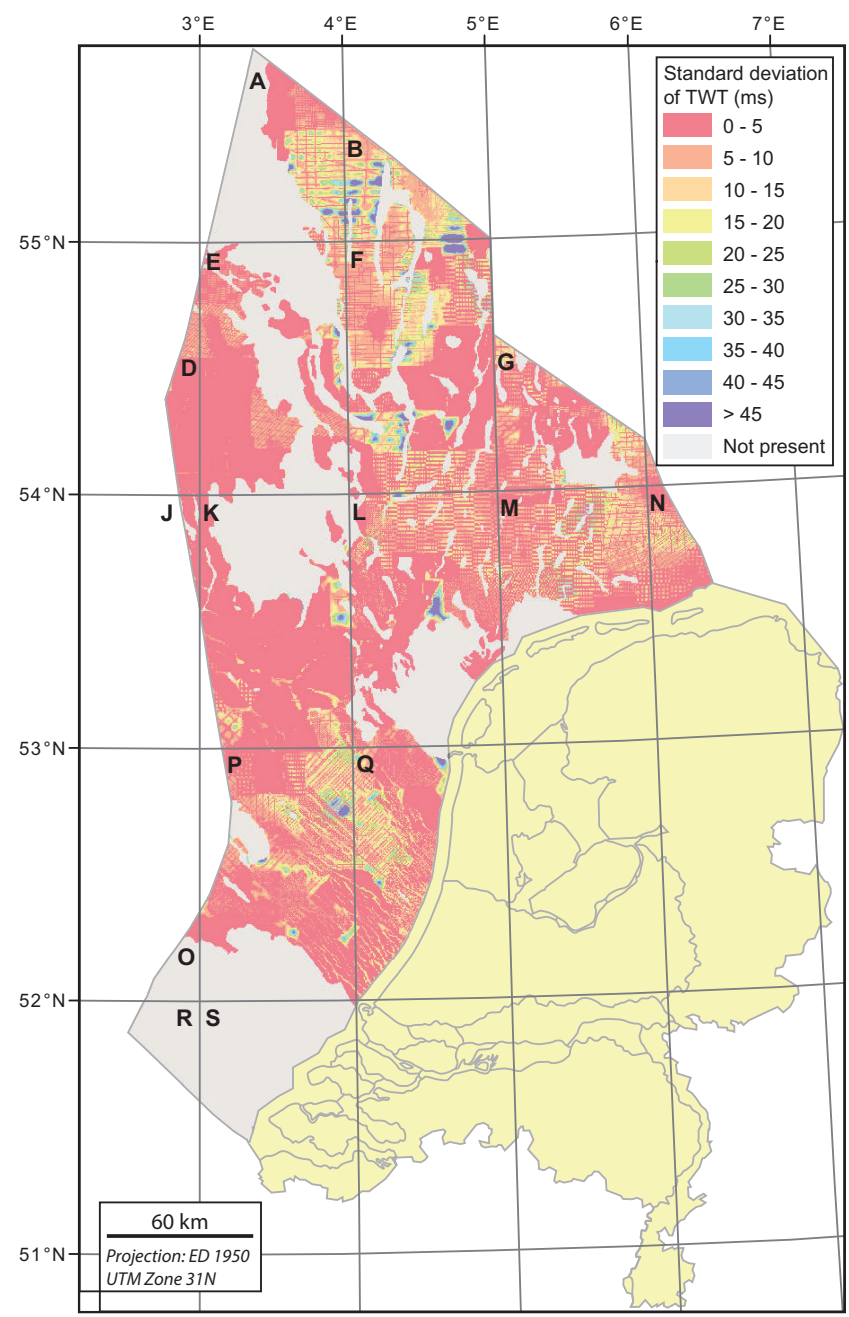

Fig. 9. Standard deviation (ms) of TWT of the base of the Lower Germanic Trias Group.
- A random realisation of a set of depth domain maps is obtained from time-depth conversion of the realised time maps using the realised $\mathrm{V}_{0}$ maps.

- Kriging interpolation of residual well marker mismatches ensures that the maps are conditioned to the wells used.

These steps are repeated until a set of 50 random realisations of time, velocity and well-tied depth maps are obtained. From this set of maps the final standard deviations are determined, representing the uncertainty of each mapping component (Figs 9 and 10). The likelihood that the real depth value lies between the estimated value plus or minus 1 times the standard deviation is ca $64 \%$. For a range of 2 times the standard deviation the likelihood is ca $95 \%$.

\section{Reservoir mapping}

Depth and thickness maps have been produced for the most important reservoir units in the offshore, thereby integrating stratigraphic well log, seismic and fault interpretations. For an example, see Fig. 11. Those reservoirs were selected where

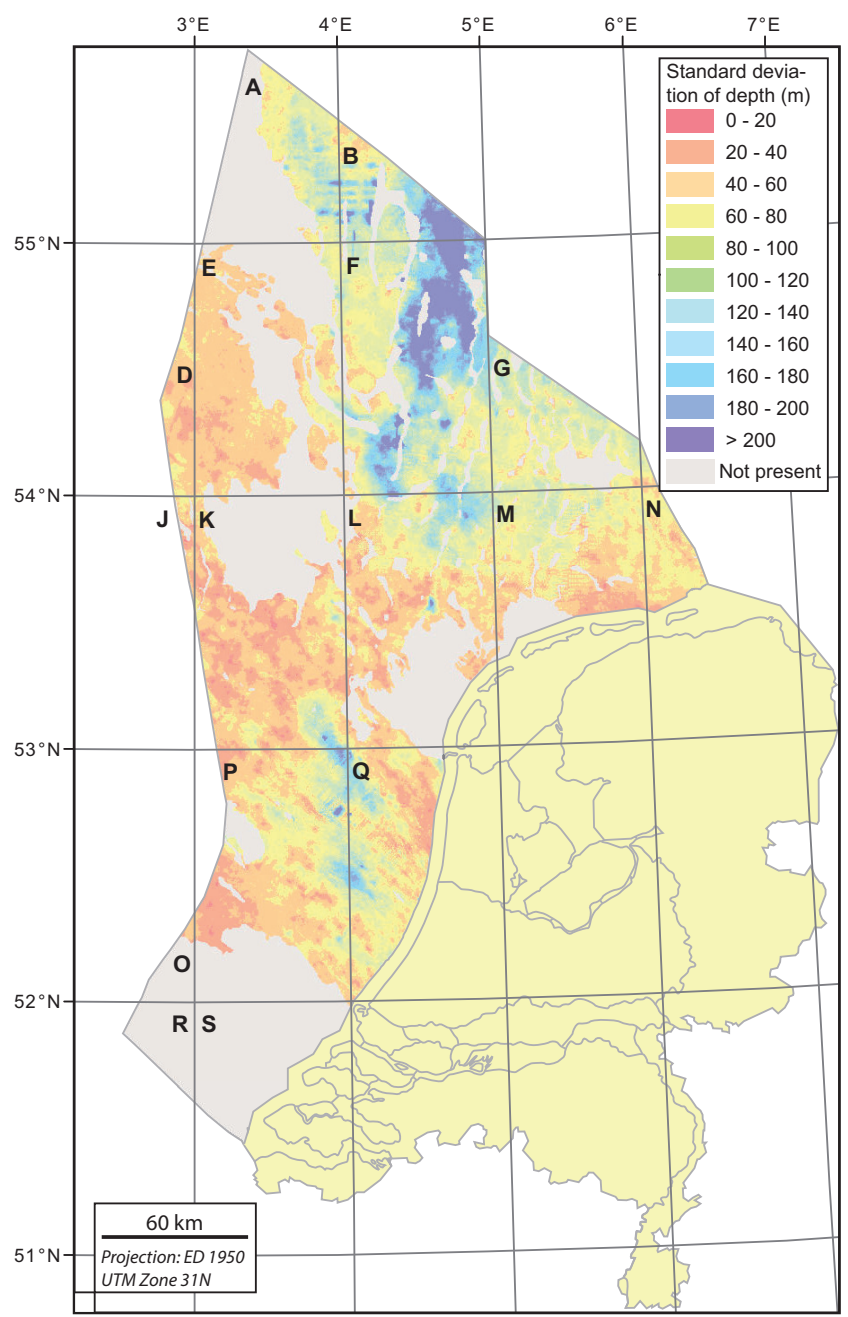

Fig. 10. Standard deviation ( $m$ ) of depth of the base of the Lower Germanic Trias Group. 


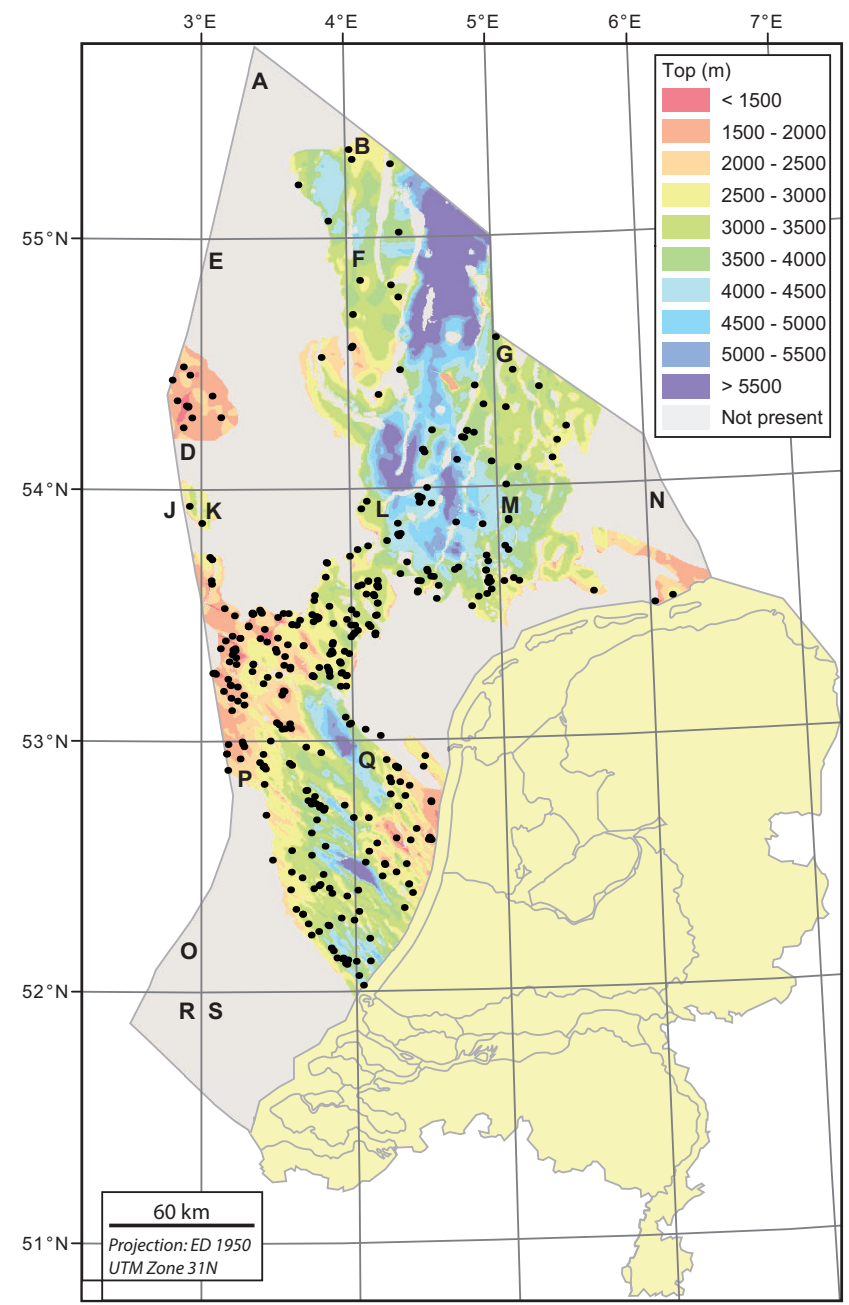

Fig. 11a. Depth of top Lower Volpriehausen Sandstone Member.

hydrocarbons have been found or which may serve as a reservoir for other purposes (e.g. geothermal heat extraction). A list of reservoirs can be found at the NLOG website.

The first step in the process is to select the appropriate wells to calculate the (true vertical) thickness of the reservoir horizon. The second step includes plotting of the wells in map view. When both the wells where the reservoir is present and absent are displayed, the areas where the reservoir is present can be delineated. Based on this information, polygons have been made within which the interpolation (reservoir depth and thickness) is performed. Major faults were used to delineate the polygons. The third step involves a further selection of wells where the reservoir is presumed present. Especially when hydrocarbon fields occur within the area to be mapped, many wells plot in clusters while the density of wells in between these clusters is much less. This unequal distribution causes an irregular surface when processed. Therefore, some of the clustered wells have been discarded. This results in a best approximation of the thickness across the area where the reservoir is thought to be present.

In case, the base of the reservoir is also the base of the mapped horizon the latter was taken as the base of the reservoir to keep the model consistent. The same applies to reservoirs

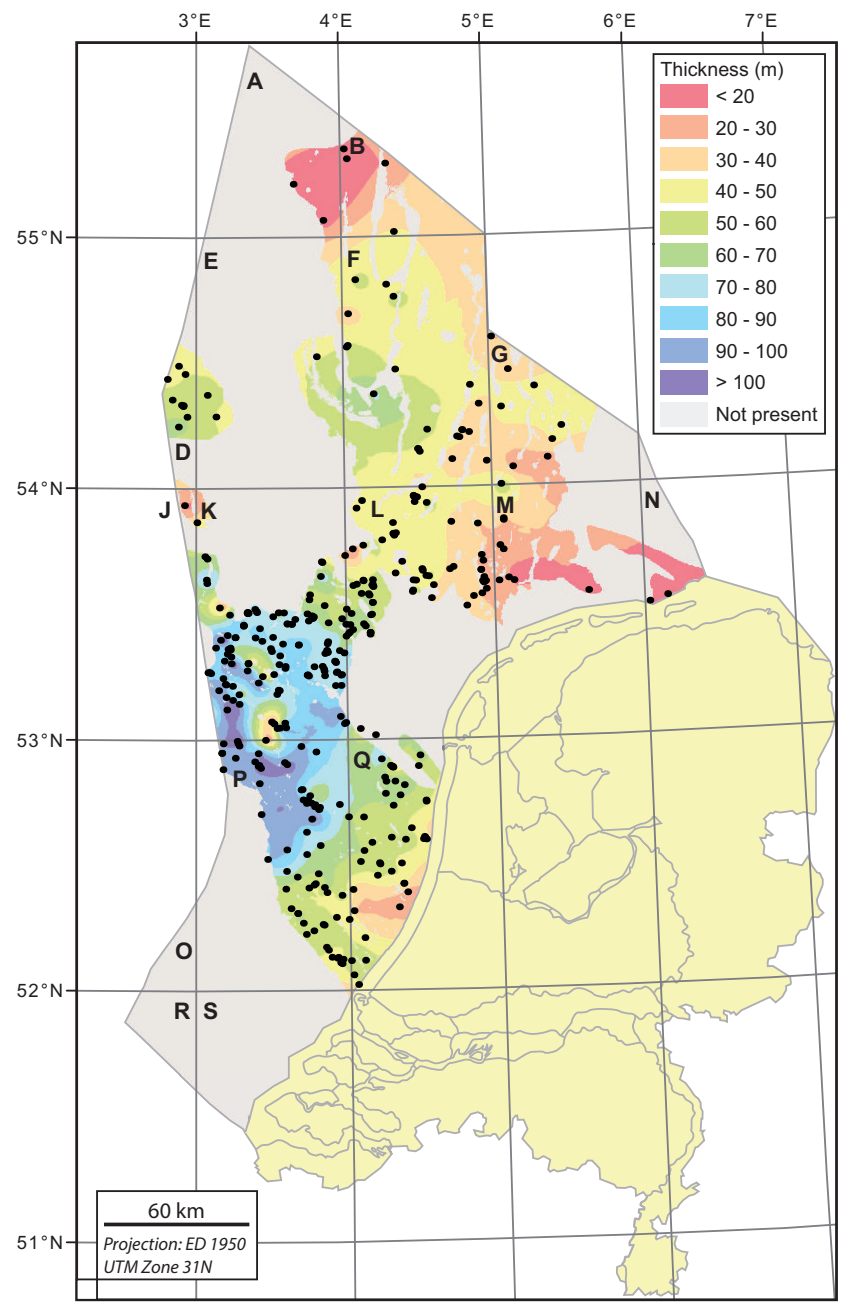

Fig. 11b. Thickness of Lower Volpriehausen Sandstone Member.

that occur on top of each other, for example the Triassic sandstones of the Lower and Upper Volpriehausen Sandstone members. When modelled separately, the top and the base of respectively the Lower and Upper Volpriehausen Sandstone members might intersect and their lateral extent might differ. Since the model has to be geometrically and stratigraphically correct, the base of the upper reservoir is maintained and used as the top of the underlying one.

\section{Structural elements}

Most structural elements in the subsurface of the Netherlands were formed during Late Jurassic and Early Cretaceous Late Kimmerian rifting (De Jager, 2007), often as a result of reactivation of Paleozoic fault systems. Since the publication of the first detailed structural elements map, compiled by Heybroek (1974), structural elements in the Netherlands on- and offshore area have been continuously (re)named and (re)mapped (NAM \& RGD, 1980; Van Wijhe, 1987). Revised versions of these maps were published by van Adrichem Boogaert and Kouwe (1993). Duin et al. (2006) presented the most recent series of structural element maps. When comparing the first structural element maps 
of Heybroek (1974) with later versions, it is evident that there is general agreement on the existence of elements, but that exact localities, outlines and structural interpretations vary.

In the most recent structural elements maps (Duin et al., 2006) it is, in some cases, unclear where the boundary between elements is located. For instance, the Cleaverbank High is poorly delineated. In addition, the names of the structural elements are not consistent. For instance, the term 'high' is used for both the Schill Grund High (SGH) and the Texel-IJsselmeer High (TIJH), despite their difference in development and burial history. On the TIJH, Cretaceous rocks directly overlie Carboniferous rocks, whereas the SGH shows a succession of Cretaceous, Triassic and Permian rocks, overlying Carboniferous sediments.

These shortcomings thus justify an update of the structural elements map in which 1) the boundaries between all elements are clearly defined and available as GIS product and 2) the names of the elements reflect the structural style of that element as much as possible.

A first order classification of structural elements distinguishes between highs, platforms and basins. This classification is not new, but a few elements previously interpreted as high were renamed as platform in this paper (all individual changes will be elaborated on below). Similar to the description of elements in the paper of Duin et al. (2006), here the term 'structural element' is assigned to regional structures with a uniform deformation history in terms of subsidence, faulting, uplift and erosion during a specific time interval. A high is defined as an area with significant non-deposition and erosion down to Carboniferous or Permian strata (Rotliegend and/or Zechstein). A platform is characterised by the absence of Lower and Upper Jurassic strata due to Late Jurassic erosion down to the Triassic. The term graben is used for a fault-bounded basin and where, in general, Jurassic sediments are preserved. For both platforms and basins, a further subdivision has been made. Platforms may either represent 1) areas where Cretaceous rocks overlie Triassic rocks or 2) areas where Cretaceous rocks lie directly on top of Permian sediments. Since most Jurassic basins in the Netherlands were subject to inversion during Late Cretaceous and Paleogene times, a subdivision is made between basins that experienced strong inversion (absence of Upper Cretaceous and older rocks) or mild inversion (presence of Lower and Upper Cretaceous rocks). The objective of a structural elements map is to distinguish between areas that experienced markedly different burial and erosion history. Structural elements are often bounded by fault zones/ systems. Therefore the main fault systems have been included in the structural elements map and new boundaries have been drawn along faults as much as possible.

For the delineation of the structural elements, grid masks of the main stratigraphic horizons present in the 3D layer model were made. Each of these grid masks represent the areal coverage of the corresponding stratigraphic horizon and is assigned a unique qualifier from the successive power of two series $(1,2,4$, 8,16 etc.). By stacking the grid masks, at each grid cell location
$(250 \times 250 \mathrm{~m})$ the layer model is perturbed, which results in a unique number for each type of stratigraphic sequence. A specific structural evolution and/or style can result in several of these stratigraphic sequences. Therefore the sequences are grouped into specific classes (here referred to as stratpiler classes) that comply with the definition of highs, platforms and basins as much as possible, as illustrated in Fig. 12.

Although this method does not differ significantly from the structural elements definition on the basis of thickness and depth maps (as being used in previous versions of structural element maps), it allows the user to interactively change the classes so that the amount of detail can be adjusted to the user's wish. For instance, the degree of tectonic inversion can be visualised by focusing on the presence or absence of specific stratigraphic intervals in the range Jurassic - Upper Cretaceous. It also enables construction of subcrop maps, by filtering out those stratigraphic sequences for which the 'underburden' needs to be determined.

In Fig. 12 a map is presented based on the stratpiler method as described above. It primarily shows the degree of inversion that took place in Late Cretaceous - Paleogene times, in addition to the presence of salt pillows (thickness between 1000-1500 m) and diapirs or walls (thickness $>1500 \mathrm{~m}$ ). Inversion severely affected the Central Netherlands Basin where Cenozoic rocks locally overlie the Lower Germanic Triassic Group (RB). In the Roer Valley Graben, Lower Cretaceous rocks are missing (mainly non-deposition); post-inversion Upper Cretaceous rocks overlie Lower to Middle Jurassic sediments. The difference between salt pillows and diapirs is based on the local sedimentary succession. In case of diapirs, the top of the Zechstein is overlain by Cenozoic or Cretaceous rocks while pillows are characterised by the presence of conformable Triassic rocks.

A simplified version of the stratpiler classes presented in Fig. 12 is given in Fig. 13, which shows the newly defined structural elements map for the Netherlands including the main fault zones. The boundaries between the structural elements acknowledge the results obtained in the stratpiler method as much as possible. Here, a short description and explanation is given for newly defined structural elements and those elements that changed name or areal extent. The elements that have been discarded with respect to the previous versions will be also discussed.

\section{Ameland Platform (AP, new)}

The Ameland Platform replaces the former Ameland Block. On the platform Lower and Upper Cretaceous and Cenozoic overlie Triassic rocks. In the west, it is sharply bounded by the Terschelling Basin where Upper Jurassic rocks are found. In the north and southwest, the Rifgronden and Hantum fault zones form the boundaries with the Schill Grund and Friesland Platforms respectively. In the southeast, the Ameland Platform passes into the Groningen Platform (top Rotliegend is at shallower level) and the Lauwerszee Trough. 


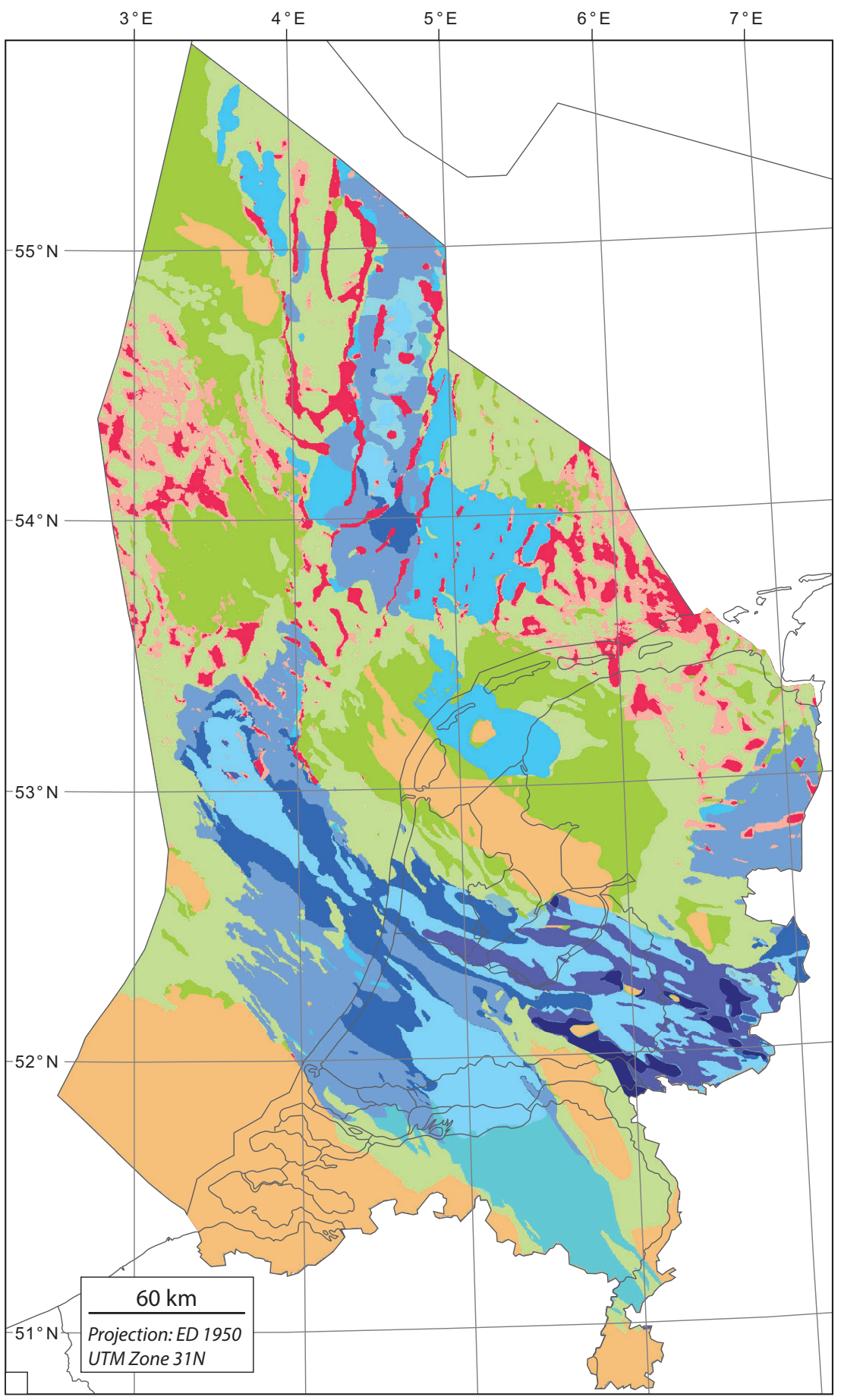

Legend
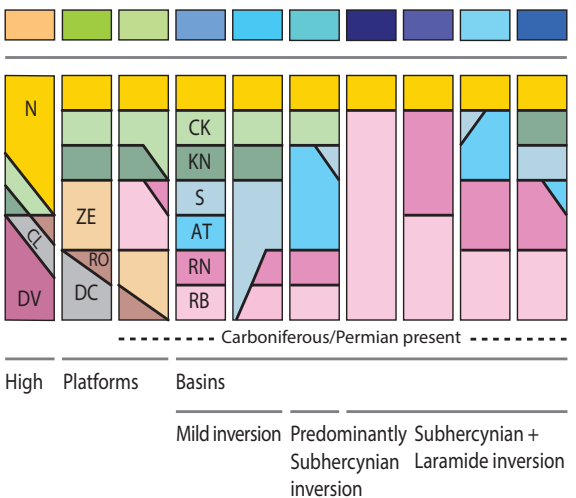

Stratigraphy

\begin{tabular}{ll}
\hline N & North Sea Super Group (Cenozoic) \\
CK & Chalk Group (Late Cretaceous) \\
KN & Rijnland Group (Early Cretaceous) \\
S & Upper Jurassic groups (Late Jurassic) \\
AT & Altena Group (Early/Middle Jurassic) \\
RN & Upper Germanic Trias Group (Late Triassic) \\
RB & Lower Germanic Trias Group (Early Triassic) \\
ZE & Zechstein Group (Late Permian) \\
RO & Lower and Upper Rotliegend groups (Late Permian) \\
DC & Limburg Group (Late Carboniferous) \\
CL & Carboniferous Limestone group \\
DV & Devonian and older \\
& Salt ridges + diapirs \\
& Salt pillows
\end{tabular}

Fig. 12. Geological map based on the stratpiler analysis, showing the degree of inversion that took place in Late Cretaceous - Paleogene times and the presence of salt pillows and diapirs.

\section{Broad Fourteens Basin (BFB)}

The Broad Fourteens Basin is a strongly inverted Jurassic basin that probably had a connection to the Central Graben in the main rifting period (Late Jurassic - Early Cretaceous times), although minor faulting occurred already in Permian and Triassic times (Hooper et al., 1995; Verweij \& Simmelink, 2002). Due to Late Cretaceous inversion, the Upper Cretaceous Chalk has been entirely removed in the greatest part of the basin. This applies to the Lower Cretaceous to a lesser extent (Fig. 12). In the southwest, the transition into the West-Netherlands Basin runs across a fault system that also comprises the IJmuiden Platform.
The boundary to the Central Netherlands Basin is gradual and has therefore been defined at the coast.

\section{Central Offshore Platform (COP)}

The Central Offshore Platform surrounds the northwestern part of the Texel IJsselmeer High and as such forms a transition zone to the Terschelling, Vlieland and Broad Fourteens basins and the Dutch Central Graben. It is likely that parts of the COP were flooded in Jurassic times in order to connect the Vlieland Basin to the Terschelling Basin and the Broad Fourteens Basin to the Dutch Central Graben. The lineament which forms the 


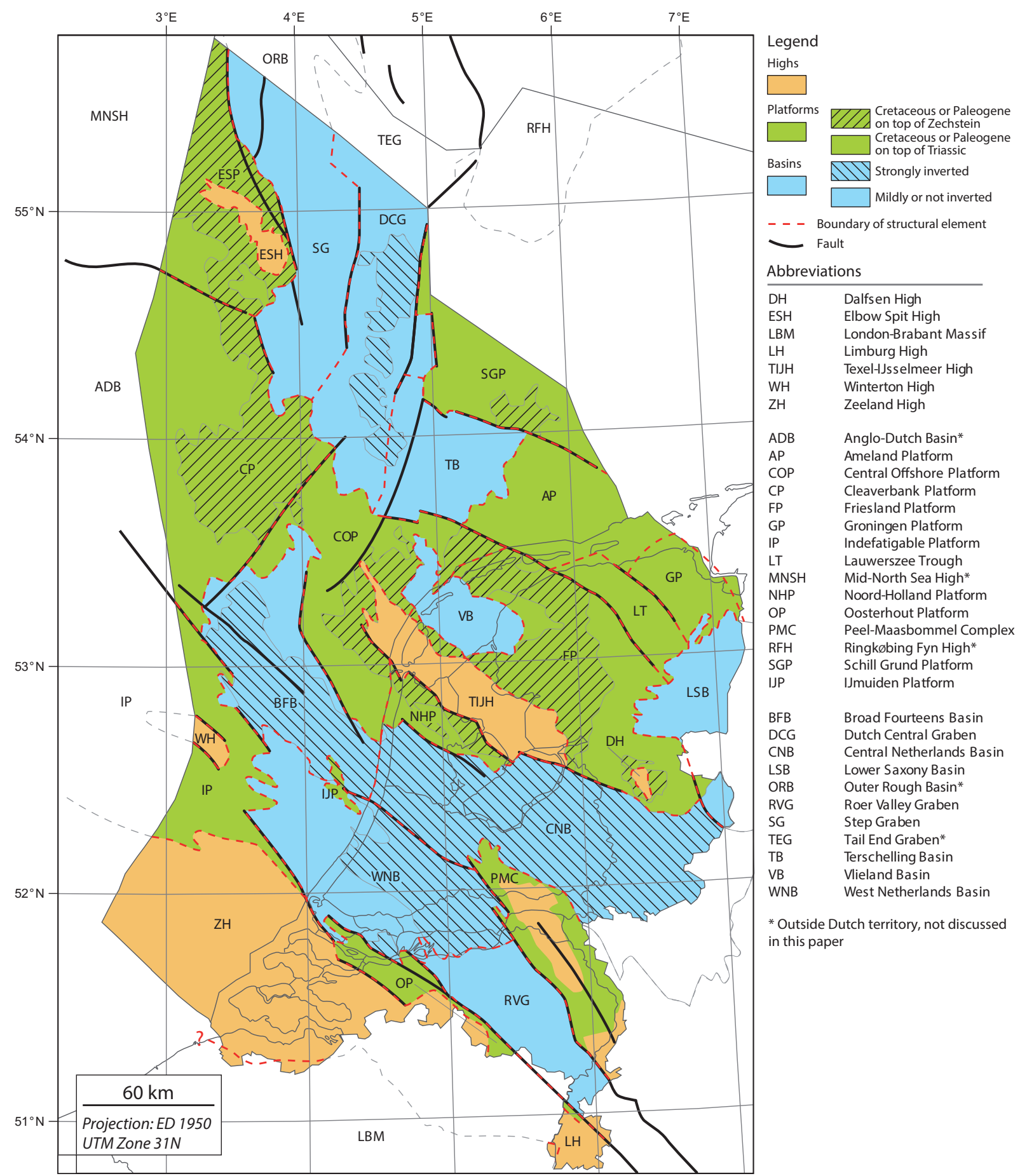

Fig. 13. Late Jurassic - Early Cretaceous structural elements of the Netherlands. The information from the border-regions is based on Best et al. (1983); De Jager (2007); Drozdzewski et al. (1985); Japsen et al. (2003); Langenaeker (2000); Lyngsie et al. (2006); Pharaoh et al. (2010) and Verniers \& Grootel (1991). Faults that terminate at the border may well continue but have not been mapped within the project.

boundary with the Cleaverbank Platform can be easily recognised on the base Cretaceous depth map (Fig. 7g) as well as on the base Rotliegend map (Fig. 7a).

\section{Central Netherlands Basin (CNB)}

The Central Netherlands Basin does not entirely fit the classification scheme. In the area now indicated as CNB only some patches of Jurassic rocks are preserved. However, it is likely that Jurassic sediments had a wider distribution. These have been eroded by Late Jurassic erosion (evidenced by the presence of Upper Jurassic and Lower Cretaceous rocks in places (dark green in Fig. 12) and strong Late Cretaceous inversion (Nelskamp, 2011). The outline of the CNB represents the area where the Upper Cretaceous is missing.

In previous papers and maps, the southwestern boundary of the CNB has been formed by the Zandvoort Ridge (ZR). In the 
current map, the ZR is not defined because of the fact that it does not stand out in stratigraphic sense. The former ZR is acknowledged in such a way that it forms the boundary zone of reverse faulting between the CNB and the WNB and is part of the Mid-Netherlands Fault Zone (Nelskamp, 2011). In the east, the CNB continues into Germany. The Gronau Fault Zone separates it from the Lower Saxony Basin. To the west, the coast marks the transition into the Broad Fourteens Basin.

\section{Cleaverbank Platform (CP, new)}

The Cleaverbank Platform replaces the Cleaverbank High. In Mid and Early Cretaceous times, the CP probably acted as a stable block where previously deposited Jurassic, Triassic and even Permian (Zechstein) sediments were eroded. The boundaries of the Cleaverbank Platform have been placed at major fault systems. The northern boundary is a lineament where the depth of the base Zechstein and Rotliegend show an abrupt change. This area is not mapped in detail due to a lack of data coverage. Moreover, this lineament links to the Hantum Fault Zone north of the Terschelling Basin. To the east, the Cleaverbank Platform passes into the Step Graben. In the southeast, another lineament marks the transition to the Central Offshore Platform and the Broad Fourteens Basin. This lineament probably connected the Central Graben and the Broad Fourteens Basin in Jurassic times. It is well visible in the base Upper Cretaceous map (Fig. 7h). In the west, the Cleaverbank Platform corresponds to the AngloDutch Basin in the UK sector.

\section{Dalfsen High (DH)}

The Dalfsen High is a relatively small isolated high on the Friesland Platform that is characterised by Cretaceous sediments on top Carboniferous rocks. In the area surrounding the $\mathrm{DH}$, the Triassic has been eroded (Fig. 12), which points to a Jurassic or more recent phase of uplift.

\section{Dutch Central Graben (DCG)}

Major extensional faulting in the Dutch Central Graben started during the Late Jurassic, but the area might have been a structural low even since Carboniferous times (van Adrichem Boogaert \& Kouwe, 1993). The basin was severely inverted during Late Cretaceous and Paleogene times, leading to removal of the entire Cretaceous succession in places. Post-inversion Chalk of youngest Cretaceous to earliest Paleocene age occurs in places. The Central Graben is fault-bounded in most areas. Extensive salt diapirs formed simultaneously with extensional faulting.

\section{Elbow Spit High (ESH)}

The Elbow Spit High is an area where the Carboniferous is partly eroded or not deposited and where Upper Cretaceous sediments overlie Devonian or Carboniferous rocks. The existence of a magmatic body of Early Devonian age probably explains the buoyant nature of the ESH, similar to the ones described in UK waters (Donato et al., 1983). During the Mid-Kimmerian rifting-related thermal uplift, the ESH was situated at the southern edge of the dome in which the entire Triassic and Permian cover was eroded. In the northeast the ESH is faultbounded, while the southwestern margin gradually dips to the Elbow Spit Platform.

\section{Elbow Spit Platform (ESP, new)}

The Elbow Spit Platform, together with the Elbow Spit High, can be regarded as the southeastern continuation of the Mid North Sea High to the northwest. In this paper it has been decided to split up this area in a high and platform, which is in closer agreement with the definition of the other platform areas. The ESP is characterised by the presence of Cretaceous and (only in the south) Triassic sediments overlying Permian rocks. To the east, the ESP is bounded by the Step Graben, via some clearly developed normal faults. In the south, a (still poorly constrained) lineament marks the transition to the Cleaverbank Platform where the depth of the Zechstein and Rotliegend increases significantly.

\section{Friesland Platform (FP)}

The Friesland Platform represents a large and geologically diverse area. The platform experienced Middle to Late Jurassic erosion (Mid and Late Kimmerian unconformity). In the northeastern and southern part of the Friesland Platform, the Triassic can reach a thickness up to $800 \mathrm{~m}$. In the northeast, the Friesland Platform is fault-bounded by the Lauwerszee Trough. Towards the southwest, the Texel-IJsselmeer High forms the boundary. In the northwest, the Friesland Platform passes into the Late Jurassic - Early Cretaceous Vlieland Basin and in the southeast towards the Lower Saxony Basin.

\section{Groningen Platform (GP, new)}

Although the former Groningen High is a well-known element because of the presence of the Groningen gas field, it should classify as a platform according to the scheme used here (absence of Jurassic rocks, presence of Triassic and Lower Cretaceous rocks). Therefore, it is proposed to use the term Groningen Platform (GP) instead of Groningen High. Although the GP does not form a separate structure based on the stratpiler analyses (the succession of rocks in the GP and the surrounding areas is nearly the same (Fig. 12)), it was decided to acknowledge the GP as a single element because of its importance in terms of petroleum geology. Moreover, the Lauwerszee Trough in the west is a marked element and the bounding faults played an important role throughout geological history. The outlines of the Groningen Platform are comparable with the outlines of the Groningen High as published before (Van Adrichem Boogaert \& Kouwe, 1993). In the west, it is bounded by the Hantum Fault Zone that marks the transition into the Lauwerszee Trough. In the south, the GP borders the Lower Saxony Basin. To the north and east, the depth of the base of the Zechstein most clearly delineates the boundary of the GP (Fig. 7b). 


\section{Indefatigable Platform (IP)}

The Indefatigable Platform surrounds the Winterton High and corresponds to the similarly named platform area in UK waters. The IP is characterised by Triassic and Cretaceous sediments on top of Permian rocks. Many NW-SE trending faults dissect the platform area. In north and east, the platform area is bounded by faults delineating the Broad Fourteens and West-Netherlands Basins. The Zeeland High is found at the southern margin of the IP where Early Cretaceous and Triassic rocks are missing.

\section{IJmuiden Platform (IJP)}

The IJmuiden Platform is part of the transition zone between the Central Netherlands, Broad Fourteens and West-Netherlands Basin, where several upthrown blocks can be found. The IJP is part of the Mid-Netherlands Fault Zone (van Adrichem Boogaert \& Kouwe, 1993) which runs from the IJP towards the southern boundary of the Peel-Maasbommel Complex (Fig. 13).

\section{Lauwerszee Trough (LT)}

The Lauwerszee Trough already formed a basin in Early Carboniferous times when carbonate deposition occurred on both the Friesland and Groningen Platforms while the LT was probably a site of (distal) turbiditic and fine-grained sedimentation (Kombrink et al., 2010). It is bounded by two major fault systems in the west and east. The Mesozoic and Cenozoic successions of the LT do not differ markedly in thickness from the adjacent Friesland and Groningen Platforms; i.e. the bounding faults have not been extensively reactivated. However, the normal fault movement that took place created sealing faults, which caused the Rotliegend to be gas-bearing with an independent GWC with respect to the Groningen Platform (De Jager \& Geluk, 2007).

\section{Limburg High (LH)}

The Limburg High is the southeasternmost extension of the Zeeland High. In this area, Upper Cretaceous deposits directly overlie Carboniferous rocks. It is bounded in the north by the Oosterhout Platform, where Triassic rocks are found. In the south, east and west, the Limburg High gives way to the adjacent fault blocks in Germany and Belgium.

\section{London-Brabant Massif (LBM)}

According to the definition of Legrand (1968) the LondonBrabant Massif is the area where Upper Cretaceous or younger sediments overlie Cambro-Silurian rocks. Only the southernmost part of the province of Zeeland and a small area in the southwest of Limburg are therefore part of the LBM. Further north, the Devonian and Carboniferous overlie the Cambro-Silurian folded succession, which is in this paper attributed to the Zeeland High.

\section{Lower Saxony Basin (LSB)}

the LSB is a strongly inverted Jurassic basin. Since its depocentre was situated in NW Germany, the Dutch part of the basin forms a marginal area only. The Friesland and Groningen Platform border the LSB to the northwest. The Gronau Fault Zone separates the LSB from the Central Netherlands Basin in the southwest. The LSB was not strongly inverted during the Late Cretaceous.

\section{North Holland Platform (NHP)}

The North Holland Platform is to be found just south of the Texel-IJsselmeer High, in the province of North Holland. It is characterised by a heavily faulted Triassic succession, overlain by Cretaceous rocks. Towards the south, the NHP is bounded by the inverted Central Netherlands Basin via a complex fault system. The offshore continuation of the NHP is represented by the Central Offshore Platform; the boundary between the two being the coast because of the absence of a distinct geological feature.

\section{Peel-Maasbommel Complex (PMC, new)}

Due to the presence of numerous important faults in this area (not shown in Fig. 13) and the associated names of individual fault blocks, it was decided to lump these together in the new element Peel-Maasbommel Complex. In this way, the PMC represents the complex of NW-SE striking fault blocks that separate the Roer Valley Graben along its southwestern boundary and the Central Netherlands Basin in the northeast. Towards the southeast (Germany), the PMC passes into the Krefeld and Erkelenz Highs in Germany.

\section{Oosterhout Platform (OP, new)}

The area south of the Roer Valley Graben forms a transitional area between the Roer Valley Graben in the north and the Zeeland High in the south. Here, Triassic rock can be found overlain by Upper Cretaceous. The southern boundary of the 0osterhout Platform is defined as the area where Triassic rocks pinch out.

\section{Roer Valley Graben (RVG)}

The Roer Valley Graben is a distinct fault-bounded graben. Similar to the Dutch Central Graben, the RVG existed as a structural feature in Paleozoic times, but it is since the Jurassic that differential subsidence clearly started. Since the sediments of the Rijnland Groups (Early Cretaceous) are missing in the RVG, it is not clear which tectonic regime the RVG experienced in those times. Subsidence recommenced in Oligocene times and continues to the present day. Apart from the northwest, where the RVG passes into the West Netherlands Basin (WNB), it is surrounded by platform areas. The boundary to the WNB has been taken at the pinch-out line of Upper Cretaceous sediments. Paleogene uplift of the RVG was less severe than in the WNB, and post-inversion Chalk has been preserved in the RVG (Gras \& Geluk, 1999). 


\section{Schill Grund Platform (SGP, new)}

The boundaries of the Schill Grund Platform did not change with respect to previous versions of the structural elements map; only the name did because of the presence of Cretaceous sediments on top of Triassic or Permian rocks. In the south and the west, the SP is bounded by faults that form the transition into the Terschelling Basin and Dutch Central Graben respectively. To the north and east, the SP continues as a platform area into the German offshore area.

\section{Step Graben (SG)}

The Step Graben is an example of a structural element that does not entirely fit the classification scheme, because the Jurassic is only present locally. It forms a terrace-like structure between the Elbow Spit and Cleaverbank Platforms in the west and the Dutch Central Graben in the east. Early Jurassic sediments were probably deposited in the area, but these were subsequently eroded by the Mid-Kimmerian thermal uplift. The patchy occurrence of Late Jurassic sediments is an indication of the terrace-like development where accommodation space was created only locally in a tilt-block half-graben setting. The SG was mildly inverted in Late Cretaceous times.

\section{Terschelling Basin (TB)}

The Terschelling Basin came into existence in Latest Jurassic times when, probably due to a reorganisation of stress fields, both the northern and southern boundary faults (Hantum and Rifgronden faults respectively) were reactivated in a normal sense. The western boundary of the TB was moved westwards compared to the earlier version of the structural elements map (Duin et al., 2006). This is based on biostratigraphic work on wells F15-02, F18-01, F18-02 and L03-01 (Munsterman et al., this issue). These wells were previously located in the DCG but since the latest Jurassic succession is very similar to the one observed in the $\mathrm{TB}$, it has been decided to include those wells in the TB. The thickness of the Jurassic succession is less than in the Dutch Central Graben. Inversion of the Terschelling Basin was only mild; the Upper Cretaceous is still present across the basin area.

\section{Texel-IJsselmeer High (TIJM)}

The Texel-IJsselmeer High is a NW-SE striking tilted fault block of which the southern boundary is made up of a steep fault system while the northern margin gradually passes into the Friesland Platform. It has been a high since Carboniferous times (Rijkers \& Geluk, 1996), but most of the erosion took place in Jurassic - Early Cretaceous times.

\section{Vlieland Basin (VB)}

The Vlieland Basin has been a Late Jurassic and Early Cretaceous depocentre, which probably had a connection to the Terschelling Basin. The thickness of the Upper Jurassic - Lower Cretaceous succession is less than the other rift basins, which is explained by the buoyancy caused by the magmatic event related to the Zuidwal volcano (De Jager, 2007). Herngreen et al. (1991) suggest that the Vlieland Basin formed a pull-apart basin in between the Dutch Central Graben and the Lower Saxony Basin. Although there are many faults in the area (mainly NW-SW trend), the Vlieland Basin is not bounded by major faults similar to the other Late Jurassic basins.

\section{West Netherlands Basin (WNB)}

The West Netherlands Basin is a Jurassic Basin which was mildly to strongly inverted in Late Cretaceous and Paleogene times. The southern boundary to the Roer Valley Graben corresponds to the area where the Chalk has been completely eroded due to inversion. In the southwest, a clear faultzone marks the boundary to the London Brabant Massif or Oosterhout Platform. The transition towards the Indefatigable Platform is irregular and runs across different fault blocks. In the northeast, the boundary with the Broad Fourteens and Central Netherlands basins consists of a faultzone (also known as the Zandvoort Ridge) which also comprises the IJmuiden Platform.

\section{Winterton High (WH)}

The Winterton High is a fault block characterised by Late Cretaceous deposits overlying Carboniferous rocks. Uplift mainly took place in the Late Jurassic and Early Cretaceous, which led to the erosion of the Triassic and Permian overburden (Van Adrichem Boogaert \& Kouwe, 1993). It is likely that the Winterton High already existed in Early Carboniferous times because a carbonate platform has been interpreted in seismic data in UK waters just on the other side of the offshore boundary (Total E\&P UK, 2007).

\section{Zeeland High (ZH)}

The Zeeland High represents the area where Upper Cretaceous sediments directly overlie Devonian and Carboniferous rocks. It forms a transitional area in between the London-Brabant Massif in the south, where Late Cretaceous sediments directly overlie Cambro-Silurian rocks, and the platform areas further north where Permian up to Late Cretaceous rocks are found. The Zeeland High is equivalent to the Limburg High further to the southeast.

\section{Concluding discussion}

This paper gives an outline of a 5 years long project in which the deep subsurface of the Netherlands offshore area has been mapped. The grids describing the base of the main stratigraphic intervals are one of the most important results. In addition, the top and base of the most important reservoir units were mapped and integrated in the existing framework. These grids form a starting point for those who would like to build a detailed model of the subsurface. For the first time, the uncertainty related to interpretation and processing of the data has been assessed using an automated workflow. 
Based on the mapping results described in this paper, it was deemed necessary to update the structural elements map of the Netherlands. Boundaries between structural elements were unclear in some cases and the naming required an update too. The resulting structural element map tries to overcome these issues and aims to be a starting point for further geological research in the Netherlands.

The deep subsurface has been mapped ever since people were interested in exploring its resources. Interpretation of bounding surfaces in well-logs or cores and the subsequent $2 \mathrm{D}$ and even 3D interpretation of similar features in seismic data were published in paper sheets initially, but since the arrival of workstations maps have been predominantly made by computers. However, despite the significant increase in data and the means to process it, the products essentially remained the same so far: a set of 2D maps, stacked on top of each other. As such, the current model of the deep subsurface is a $2.5 \mathrm{D}$ rather than a 3D model. In order to be able to assign specific variables like lithology or porosity to a random point in the subsurface, a full 3D model is needed in which grid cells can be populated with certain attributes. This is common practise in the oil and gas industry, but has hardly been applied on a regional scale. In the years to come, emphasis will be put on the development of such a regional 3D model, which will result in a further integration and more possibilities to study the processes active in the subsurface.

\section{Acknowledgements}

The authors thank Carla Elmers, Jenny Hettelaar and other workers at TNO who contributed to the work presented here. Jan de Jager kindly provided comments on an earlier version of the new structural elements map. The editor Mark Geluk is thanked for his constructive reviews during multiple phases of revision. Tim Pharaoh is acknowledged for his thourough review.

\section{References}

Best, G., Kockel, F. \& Schoeneich, H., 1983. Geological history of the southern Horn Graben. Geologie en Mijnbouw 62: 25-33.

Bless, M.J.M., Bouckaert, J., Conil, R., Groessens, E., Kasig, W., Paproth, E., Poty, E., van Steenwinkel, M., Streel, M. \& Walter, R., 1980. Pre-Permian depositional environments around the Brabant Massif in Belgium, the Netherlands and Germany. Sedimentary Geology 27: 1-81.

Brouwer, G.C., 1972. The Rotliegend in the Netherlands. In: Falke, H. (ed.): Rotliegend, Essays on European Lower Permian. E.J. Brill (Leiden): 34-42.

De Jager, J., 2003. Inverted basins in the Netherlands, similarities and differences. Netherlands Journal of Geosciences 82: 355-366.

De Jager, J., 2007. Structural setting. In: Wong, T.E., Batjes, D.A.J. \& De Jager, J. (eds): Geology of the Netherlands. Royal Netherlands Academy of Arts and Sciences (KNAW) (Amsterdam): 1-23.
De Jager, J. \& Geluk, M.C., 2007. Petroleum geology. In: Wong, T.E., Batjes, D.A.J. \& De Jager, J. (eds): Geology of the Netherlands. Royal Netherlands Academy of Arts and Sciences (KNAW) (Amsterdam): 241-264.

De Lugt, I.R., 2007. Stratigraphical and structural setting of the Palaeogene siliciclastic sediments in the Dutch part of the North Sea Basin. PhD thesis, Utrecht University (Utrecht), $112 \mathrm{pp}$.

Den Hartog Jager, D.G., 1996. Fluviomarine sequences in the Lower Cretaceous of the West Netherlands Basin: correlation and seismic expression. In: Rondeel, H.E., Batjes, D.A.J. \& Nieuwenhuijs, W.H. (eds): Geology of gas and oil under the Netherlands. Kluwer Academic Publishers (Amsterdam): 229-242.

Donato, J.A., Martindale, W. \& Tully, M.C., 1983. Buried granites within the Mid North Sea High. Journal of the Geological Society 140: 825-837.

Doornenbal, J.C. \& Stevenson, A.G. (eds), 2010. Petroleum Geological Atlas of the Southern Permian Basin Area. EAGE Publications b.v. (Houten), 342 pp.

Drozdzewski, G., Engel, H., Wolf, R. \& Wrede, V., 1985. Beiträge zur Tiefentektonik westdeutscher Steinkohlenlagerstätten. Geologische Landesamt von Nordrhein-Westfalen (Krefeld), $236 \mathrm{pp}$.

Duin, E.J.T., Doornenbal, J.C., Rijkers, R.H.B., Verbeek, J.W. \& Wong, T.E., 2006. Subsurface structure of the Netherlands; results of recent onshore and offshore mapping. Netherlands Journal of Geosciences 85: 245-276.

Dunay, R.E. \& Dronkers, A.J., 1983. Stratigraphic correlation of the Vlieland and Delfland units in the Dutch offshore, based on palynology. Geologie en Mijnbouw 62: 131-134.

Geluk, M.C., 2005. Stratigraphy and tectonics of Permo-Triassic basins in the Netherlands and surrounding areas. PhD thesis, Utrecht University (Utrecht), $171 \mathrm{pp}$.

Geluk, M.C., 2007a. Permian. In: Wong, T.E., Batjes, D.A.J. \& De Jager, J. (eds): Geology of the Netherlands. Royal Netherlands Academy of Arts and Sciences (KNAW) (Amsterdam): 63-84.

Geluk, M.C., 2007b. Triassic. In: Wong, T.E., Batjes, D.A.J. \& De Jager, J. (eds): Geology of the Netherlands. Royal Netherlands Academy of Arts and Sciences (KNAW) (Amsterdam): 85-106.

Geluk, M.C., Dusar, M. \& De Vos, W., 2007. Pre-Silesian. In: Wong, T.E., Batjes, D.A.J. \& De Jager, J. (eds): Geology of the Netherlands. Royal Netherlands Academy of Arts and Sciences (KNAW) (Amsterdam): 27-42.

Gradstein, F.M., Ogg, J.G. \& Smith, A.G., 2004. A Geologic Time Scale 2004. Cambridge University Press (Cambridge), 589 pp.

Gras, $R$. \& Geluk, M.C., 1999. Late Cretaceous-Early Tertiary sedimentation and tectonic inversion in the southern Netherlands. Geologie en Mijnbouw 78: 1-19.

Herngreen, G.F.W., Smit, R. \& Wong, T.E., 1991. Tectonics and stratigraphy of the Vlieland Basin. In: Spencer, A.M. (ed.): Generation, accumulation and production of Europe's hydrocarbons. 0xford University Press (0xford): 175-192.

Herngreen, G.F.W. \& Wong, T.E., 2007. Cretaceous. In: Wong, T.E., Batjes, D.A.J. \& De Jager, J. (eds): Geology of the Netherlands. Royal Netherlands Academy of Arts and Sciences (KNAW) (Amsterdam): 127-150.

Heybroek, P., 1974. Explanation to tectonic maps of the Netherlands. Geologie en Mijnbouw 53: 43-50.

Hooper, R.J., Goh, L.S. \& Dewey, F., 1995. The inversion history of the northeastern margin of the Broad Fourteens Basin. In: Buchanan, J.G. \& Buchanan, P.G. (eds): Basin Inversion. Geological Society Special Publication (London): 307-317.

International Commission on Stratigraphy (ICS), 2003. International Stratigraphic Chart. International Commission on Stratigraphy (www.stratigraphy.org). 
Japsen, P., Britze, P. \& Andersen, C., 2003. Upper Jurassic - Lower Cretaceous of the Danish Central Graben: structural framework and nomenclature. Bulletin of the Geological Society of Denmark 1: 233-246.

Kombrink, H., Van Lochem, H. \& Van der Zwan, K.J., 2010. Seismic interpretation of Dinantian carbonate platforms in the Netherlands; implications for the palaeogeographical and structural development of the Northwest European Carboniferous Basin. Journal of the Geological Society 167: 99-108.

Kozur, H.W. \& Bachmann, G.H., 2008. Updated correlation of the Germanic Triassic with the Tethyan scale and assigned numeric ages. Berichte der Geologischen Bundesanstalt 76: 53-58.

Langenaeker, V., 2000. The Campine Basin. Stratigraphy, structural geology, coalification and hydrocarbon potential for the Devonian to Jurassic. $\mathrm{PhD}$ thesis, Leuven University (Leuven), $142 \mathrm{pp}$.

Legrand, $\boldsymbol{R} ., 1968$. Le Massif du Brabant. Mémoires Toelichtende Verhandelingen voor de Geologische en Mijnkaarten van België 9: 3-145.

Lott, G.K., Wong, T.E., Dusar, M., Andsbjerg, J., Mönnig, E., Feldman-Olszewska, A. \& Verreussel, R.M.C.H., 2010. Jurassic. In: Doornenbal, J.C. \& Stevenson, A.G. (eds): Petroleum Geological Atlas of the Southern Permian Basin Area. EAGE Publications b.v. (Houten): 175-193.

Lyngsie, S.B., Thybo, H. \& Rasmussen, T.M., 2006. Regional geological and tectonic structures of the North Sea area from potential field modelling. Tectonophysics 413: 147-170.

McCann, T. (ed.), 2008a. The Geology of Central Europe. Volume 1: Precambrian and Palaeozoic. The Geological Society (London), $748 \mathrm{pp}$.

McCann, T. (ed.), 2008b. The Geology of Central Europe. Volume 2: Mesozoic and Cenozoic. The Geological Society (London), 700 pp.

Munsterman, D.K., Verreussel, R.M.C.H., Mijnlieff, H.F., Witmans, N., KerstholtBoegehold, S. \& Abbink, O.A., 2012. Revision and update of the CallovianRyazanian Stratigraphic Nomenclature in the northern Dutch offshore, i.e. Central Graben Subgroup and Scruff Group. Netherlands Journal of Geosciences 91-4: 555-590, this issue.

NAM \& RGD, 1980. Stratigraphic nomenclature of the Netherlands. Verhandelingen van het Koninklijk Nederlands Geologisch Mijnbouwkundig Genootschap 32, 77.

Nelskamp, S., 2011. Structural evolution, temperature and maturity of sedimentary rocks in the Netherlands. PhD thesis, Rheinisch-Westfaelische Technische Hochschule Aachen (Aachen), 175.

Oncken, 0., Plesch, A., Weber, J., Ricken, W. \& Schrader, S., 2000. Passive margin detachment during arc-continental collision (Central European Variscides). In: Franke, W., Haak, V., Oncken, 0. \& Tanner, D. (eds): Orogenic Processes: Quantification and Modelling in the Variscan Belt. Geological Society Special Publications (London): 199-216.

Oncken, 0., Von Winterfeld, C. \& Dittmar, U., 1999. Accretion of a rifted passive margin; the late Paleozoic Rhenohercynian fold and thrust belt (middle European Variscides). Tectonics 18: 75-91.

Overeem, I., Weltje, G.J., Bishop-Kay, C. \& Kroonenberg, S.B., 2001. The Late Cenozoic Eridanos delta system in the Southern North Sea Basin: a climate signal in sediment supply? Basin Research 13: 293-312.

Paul, J., Wemmer, K. \& Wetzel, F., 2009. Keuper (Late Triassic) sediments in Germany - indicators of rapid uplift of Caledonian rocks in southern Norway. Norwegian Journal of Geology 89: 193-202.

Pharaoh, T.C., 1999. Palaeozoic terranes and their lithospheric boundaries within the Trans-European suture zone (TESZ); a review. Tectonophysics 314: 17-41.
Rijkers, R.H.B. \& Geluk, M.C., 1996. A tectogenetic mechanism controlling the evolution of the Texel-IJsselmeer High, the Netherlands. In: Rondeel, H.E., Batjes, D.A.J. \& Nieuwenhuijs, W.H. (eds): Geology of gas and oil under the Netherlands. Kluwer Academic Publishers (Dordrecht): 265-284.

Stegers, D.P.M., 2006. Sedimentary facies analysis of sequence 2 of the Upper Jurassic in the Terschelling Basin and the southern Dutch Central Graben. TNO-NITG, 43.

Total E\&P UK, 2007. A regional review of the Dinantian carbonate play: Southern North Sea \& onshore UK. Report number UK-REG-0278.FH, 64.

TNO-NITG, 2004. Geological Atlas of the Subsurface of the Netherlands - onshore. Netherlands Institute of Applied Geoscience TN0 (Utrecht), 104.

Underhill, J.R. \& Partington, M.A., 1993. Jurassic thermal doming and deflation in the North Sea: implications of the sequence stratigraphic evidence. In: Parker, J.R. (ed.): Petroleum Geology of North-West Europe: Proceedings of the $4^{\text {th }}$ Conference. Geological Society (London): 337-345.

Van Adrichem Boogaert, H.A. \& Kouwe, W.F.P., 1993. Stratigraphic nomenclature of the Netherlands, revision and update by RGD and NOGEPA, Section A, General. Mededelingen Rijks Geologische Dienst 50: 1-40.

Van Dalfsen, W., Doornenbal, J.C., Dortland, S. \& Gunnink, J.L., 2006. A comprehensive seismic velocity model for the Netherlands based on lithostratigraphic layers. Netherlands Journal of Geosciences 85: 277-292.

Van Dalfsen, W., Van Gessel, S.F. \& Doornenbal, J.C., 2007. VELMOD-2 Joint Industry Project. TNO Built Environment and Geosciences (Utrecht). Report number 2007-U-R1272C, 97.

Van der Molen, A.S., 2004. Sedimentary development, seismic stratigraphy and burial compaction of the Chalk Group in the Netherlands North Sea area. PhD thesis, Utrecht University (Utrecht), 175.

Van Hulten, F.F.N. \& Poty, E., 2008. Geological factors controlling Early Carboniferous Carbonate Platform development in the Netherlands. Geological Journal 43: 175-196.

Van Wees, J.D., Stephenson, R.A., Ziegler, P.A., Bayer, U., McCann, T., Dadlez, R., Gaupp, R., Narkiewicz, M., Bitzer, F. \& Scheck, M., 2000. On the origin of the Southern Permian Basin, Central Europe. Marine and Petroleum Geology 17: 43-59.

Van Wijhe, D.H., 1987. The structural evolution of the Broad Fourteens Basin. In: Brooks, J. \& Glennie, K. (eds): Petroleum Geology of North-West Europe. Graham \& Trotman (London): 315-323.

Verniers, J. \& Grootel, G.V., 1991. Review of the Silurian in the Brabant Massif, Belgium. Annales de la Société Géologique de Belgique 114: 163-193.

Verweij, H. \& Simmelink, H.J., 2002. Geodynamic and hydrodynamic evolution of the Broad Fourteens Basin (the Netherlands) in relation to its petroleum systems. Marine and Petroleum Geology 19: 339-359.

Wong, T.E., Batjes, D.A.J. \& De Jager, J. (eds), 2007a. Geology of the Netherlands. Royal Netherlands Academy of Arts and Sciences (KNAW) (Amsterdam), 354.

Wong, T.E., De Lugt, I.R., Kuhlmann, G. \& Overeem, I., 2007b. Tertiary. In: Wong, T.E., Batjes, D.A.J. \& De Jager, J. (eds): Geology of the Netherlands. Royal Netherlands Academy of Arts and Sciences (KNAW) (Amsterdam): 151-172.

Ziegler, P.A., 1990. Geological Atlas of Western and Central Europe ( $2^{\text {nd }}$ edition). Shell Internationale Petroleum Maatschappij B.V.; Geological Society Publishing House (Bath), 239. 